\title{
Kamu Kurumlarında Yapısal Güçlendirmenin Personelin Örgütsel Özdeșleșme ve Yaşam Doyumu Üzerindeki Etkileri ${ }^{1}$
}

\author{
Hafize SEÇTIM ${ }^{* *}$ Hüseyin ERKUL ${ }^{* * *}$
}

\section{ÖZET}

Yapısal güçlendirme, personelin kararlara katılımını, iş birliğini teşvik eden, onlara geliştirme firsatı, destek, kaynak ve bilgi paylaşımının sağlandığı ortam oluşturarak, bilişsel ve duyuşsal olarak güçlendirilmelerini amaçlayan bir yönetim tekniğidir. Araştırmanın konusunu kamu kurumlarında yapısal güçlendirmenin bireysel ve örgütsel etkileri oluşturmaktadır. Bu kapsamda kamu kurumlarında yapısal güçlendirmenin personelin örgütsel özdeşleşme ve yaşam doyumu üzerindeki etkileri incelenmiş; elde edilen verilerle hem alanyazına bu model vasıtasıyla katkı sağlanması hem de yönetsel kapasitenin geliştirilmesinde kamu yönetimlerine öneri sunulması amaçlanmıştır. Araştırma betimsel araştırma yöntemi kullanılarak yürütülmüş, araştırmanın verileri üniversite hastanelerinde görev yapan 538 sağlı personelinden anket tekniğiyle elde edilmiştir. Araştırmada korelasyon, regresyon analizleri gerçekleştirilmiş, araştırmanın hipotezleri yapısal eşitlik modellemesi ile test edilmiştir. Elde edilen analiz sonuçlarına göre; yapısal güçlendirme ile örgütsel özdeşleşme ve yaşam doyumu arasında güçlü ilişkiler olduğu, yapısal güçlendirmenin personelin örgütsel özdeşleşme ve yaşam doyumunu olumlu yönde etkilediği saptanmıştır. Yapısal güçlendirmenin bir yönetim tekniği olarak bireysel ve örgütsel başarı elde edilmesinde önemli bir araç olduğu sonucuna ulaşılmıştır.

\section{The Effect of Structural Empowerment on Organizational Identification and Satisfaction with Life of the Personnel}

\section{ABSTRACT}

Structural empowerment is a management technique that aims to empower cognitively and affectively by creating an environment that encourages staff participation in decisions, cooperation, and provides them with the opportunity to develop, support, resource, and information sharing. The subject of the research is the individual and organizational effects of structural empowerment in public institutions. In this context, the effects of structural empowerment in public institutions on the organizational identification and satisfaction with life of the personnel were examined; With the data obtained, it is aimed to contribute to the literature by means of this model and to offer suggestions to the public administrations in developing administrative capacity. The research was conducted using a descriptive research method, and the data of the study were obtained by questionnaire technique from 538 health personnel working in university hospitals. Correlation and regression analyzes were carried out in the study, and the hypotheses of the research were tested by structural equation modeling. According to the analysis results obtained; It was determined that there are strong relationships between structural empowerment and organizational identification and satisfaction with life and that structural empowerment positively affects the organizational identification and satisfaction with life of the staff. It was concluded that structural empowerment, as a management technique, is an important tool in achieving individual and organizational success.
Araștırma Makalesi

Geliş: 30.01.2021

Kabul: 04.03.2021

Anahtar Kelimeler:

Güçlendirme,

Yapısal Güçlendirme, Örgütsel Özdeşleşme, Yaşam Doyumu.
Research Article

Received: 30.01.2021

Accepted: 04.03.2021

Keywords:

Empowerment,

Structural

Empowerment,

Organizational

Identification,

Satisfaction with Life.

${ }^{1}$ Prof. Dr. Hüseyin ERKUL danışmanlığında yürütülen "Kamu Kurumlarında Yapısal Güçlendirmenin Personelin Örgütsel Özdeşleşme ve Yaşam Doyumu Üzerindeki Etkileri: Trakya Üniversiteler Birliği Araştırma ve Uygulama Hastaneleri Örneği” başlıklı doktora tezinden üretilmiştir

** Dr. Çanakkale Onsekiz Mart Üniversitesi, Lisansüstü Eğitim Enstitüsü, Kamu Yönetimi Doktora Mezunu, sectimhafize@gmail.com, ORCID ID: https://orcid.org/0000-0001-8671-0828

*** Prof. Dr. Çanakkale Onsekiz Mart Üniversitesi, Siyasal Bilgiler Fakültesi, Kamu Yönetimi ABD, hcerkul@comu.edu.tr, ORCID ID: https://orcid.org/0000-0002-8856-696X 


\section{GİRiş}

Günümüzde kamu kurumlarında personelin daha fazla karar mekanizmalarına katılımı desteklenmekte, hiyerarşinin yataylaşmasına, personelin eğitim ve geliştirilmesine, bilginin paylaşılmasına daha fazla önem verilerek etkinliğin ve verimliliğin artırılması hedeflenmektedir. Bu doğrultuda çalışanların güçlendirilmesi önemli bir rol oynamaktadır.

Post-modern yönetim yaklaşımında kamuya sunulan hizmetlerin odağına "insan” öğesi alınmıştır. Dolayısıyla hizmetten yararlananlar kadar hizmeti sunanlarında yapısal olarak güçlendirilmesi toplumsal verimlilik olarak yansıyacaktır. Bu yaklaşımların önemli aktörü olan kamu kurumlarında görev yapan personelin güçlendirilmesi önem kazanırken, yöneticiler bu firsatı sağlayan bir postmodern yönetim tekniği olarak yapısal güçlendirme uygulamalarına giderek daha fazla önem vermektedir.

Yapısal güçlendirme, personelin kararlara katılımını, iş birliğini teşvik eden, kendini geliştirme fırsatı, destek, kaynak ve bilgi paylaşımının sağlandığı ortam oluşturarak onların bilişsel ve duyuşsal olarak güçlendirilmelerini amaçlayan bir yönetim tekniğidir. Yapısal güçlendirme ile personelin iş ile ilgili kendini geliştirmelerine firsat sağlanmakta, yaratıcılıkları teşvik edilmekte, işleriyle ilgili inisiyatif kullanmaları desteklenmektedir. Böylece örgütsel güven, öz yeterlilik, iş doyumu, örgütsel bağl1lık ve psikolojik güçlendirme gibi birçok olumlu sonuçlar elde edilebilmektedir. Çünkü yapısal güçlendirme çalışanların işlerine karşı algılarını ve performanslarını olumlu yönde etkilemekle birlikte hem bireysel hem de örgütsel başarılar elde edilmesinde önemli katkılar sağlayabilmektedir.

Araştırmada, kamu kurumlarında yapısal güçlendirme uygulamalarının personel üzerindeki etkileri; örgütsel sonuç olarak örgütsel özdeşleşme ve bireysel sonuç olarak yaşam doyumu ele alınarak incelenmiştir. Bu doğrultuda kamu kurumlarına yönelik geliştirilen yapısal güçlendirme ölçeğinin kamu kurumu personelinde test edilmesi ve yapısal güçlendirme uygulamalarının personelinin örgütsel özdeşleşme ve yaşam doyumu algısı üzerindeki etkisinin incelenmesi amaçlanmıştır. Kamu kurumlarında kurumsallaşma düzeyi, personele sağlanan örgütsel destek, kaynaklar, insan kaynakları politikaları ile eğitim ve geliştirme firsatlarının; personelin örgütsel özdeşleşme ve bu kapsamda sadakat ve üyelik-benzerlik düzeyleri yanı sıra, yaşam doyumu düzeyleri üzerindeki etkilerinin incelenmesi hedeflenmiştir. $\mathrm{Bu}$ sayede kamu kurumlarındaki uygulamaların personel üzerindeki etkileri test edilerek, kamu kurumlarına yönelik geliştirilen ölçeğin kullanıldığı bu model vasıtasıyla alanyazına katkı sağlanması ve bununla birlikte, elde edilen veriler ile kamu kurum yönetimlerine, yönetsel kapasitenin artırılmasına yönelik öneriler sunulması amaçlanmıştır. 
Araştırmada öncelikle yapısal güçlendirmenin kuramsal temelleri, ardından kamu kurumlarında yapısal güçlendirme, örgütsel özdeşleşme ve yaşam doyumu kavramları açıklanmıştır. Sonrasında kamu kurumlarında yapısal güçlendirme alan araştırması hakkında açıklamalar yapılarak elde edilen bulgulara yer verilmiştir. Elde edilen bulgular tartışıldıktan sonra sonuç ve öneriler sunulmuştur.

\section{YAPISAL GÜÇLENDİRMENIN KURAMSAL TEMELLERİ}

Bilim ve teknolojideki ilerlemeler, küreselleşme eğilimi, hizmet beklentilerinde yaşanan değişimler gibi gelişmeler, örgütlerin personelinden beklentilerini de artırmaktadır. Değişen koşullarda, postmodern yönetim tekniği olarak personel güçlendirme ise önem kazanmaktadır. Personel güçlendirme, alanyazında genel olarak iki farklı bakış açısıyla ele alınmaktadır. Güçlendirmenin mekanik yaklaşımı, örgütün açıkça tanımlanmış vizyon ve amaçlarının üst yönetim tarafından belirlendiği ve her kademeye yayıldığı bir tavandan tabana yaklaşıma (top-down) odaklanmaktadır. Güçlendirmenin organik yaklaşımı ise tabandan tavana (bottom-up) yayılan; personelin ihtiyaçlarının anlaşılmasına, istenilen davranışların oluşmasında model olunmasına, ekip çalışmasına, çalışanların risk almalarında cesaretlendirilmesine ve yaptıkları işlerde onlara güvenmeye odaklanmaktadır (Quinn ve Spreitzer (1997: 37-39). Yapısal ve yönetsel uygulamalara dayanan yapısal güçlendirme, güçlendirmenin mekanik yaklaşımı olarak ifade edilmektedir.

Yapısal güçlendirmenin kuramsal temelleri incelendiğinde; 1970'lerde, yazınsal alanda; otonomi, iş tasarımı, motivasyon gibi alanları içeren araştırmalarda, daha çok personelin nasıl güçlendirileceği üzerine tanımlandığı ve çalışanların güçlendirilmesine olanak sağlayacak kurumsal sistemlerin oluşturulması gerektiğinin üzerinde durulduğu görülmektedir. Genel olarak yapılan araştırmaların ortak noktasının, personelin işlerinde karar verebilme özgürlüğünün çalışanları motive edeceği ve yapısal güçlendirmenin örgütlerde otonomiyi artırmanın en iyi yolu olduğu, onları zorlayıc1 görevleri başarmada motive edeceği iddiaları olduğu ifade edilebilir (Hackman ve Oldham, 1976; Bandura, 1977; Kanter, 1977; Conger ve Kanungo, 1988). Kanter’ in (1977) yapısal güçlendirme çalışmaları bu alanda yapılan ilk çalışmalar arasında dikkat çekmektedir. Kanter (1977), "Şirketin Kadın ve Erkekleri” isimli kitabında; insanların içinde bulundukları çalışma koşulları ve ortamlarında rasyonel tepkiler verdiklerinden bahsetmiştir. Çalışma ortamı personelin kendilerini güçlenmiş hissettikleri bir şekilde yapılandırıldığında, personelin motivasyonları artmakta ve karşılaştıkları zorluklarla daha kolay baş edebilmektedirler.

Yapısal güçlendirmenin kuramsal temellerini atan Kanter (1977) gücü; “işleri başarmak için kaynakları seferber etme yeteneği” olarak tanımlamıştır (Kanter, 1977: 166). Kanter’e göre yapısal güç; sistemsel güç faktörleri (systemic power factors), iş ile ilgili güçlendirme yapılarına ulaşım 
(Access to job-related empowerment), bireysel etki (personal impact) ve iş etkinliği (work effectiveness) ile dört parçadan oluşmaktadır.

Otonomi kullanabilme, işin görünürlüğü, esnekliği gibi resmi güç kaynakları ile örgüt içi ve dışındaki paydaşlarla kurulan sosyal ilişkileri içeren gayri resmi güç kaynakları, "sistemsel güç faktörleri”ni oluşturmaktadır. Sistemsel güç faktörleri, “iş ile ilişkili güçlendirme yapılarına ulaşım”ı (fırsat yapısı ile bilgi, destek ve kaynaklardan oluşan güç yapısı) etkilemektedir. Bu etki sonucunda personel üzerinde artan öz yeterlilik, motivasyon, örgütsel bağlllık, iş doyumu ve azalan tükenmişlik, iş stresi gibi "bireysel etkiler” oluşmaktadır. Böylece onların başarma duygusu, ekip çalışması ve memnuniyet düzeyi gibi “iş etkinlikleri” de artırmaktadır (Almost ve Laschinger, 2002: 411). Dolayısıyla güç; personelin bireysel özelliklerden ziyade, örgütün güçlenme duygusunu teşvik eden resmi araçlarından kaynaklanmaktadır. Örgütsel başarının sırrı personele başarma firsatı sağlayan bir yapıdan geçer. Örgütün yapısal özelliklerinin güçlendirilmesi, personelin kişilik özelliklerinden daha fazla güçlenmeyi etkilemektedir. Böylece bireysel davranışlar veya özellikler ne olursa olsun, örgütsel yap1 veya iş özellikleri, optimum iş performansını sınırlandırabilmekte veya artırabilmektedir (Kanter, 1977; Conger ve Kanungo, 1988; Thomas ve Velthouse, 1990; Spreitzer 1995; Laschinger, 1996).

Kanter (1977: 129-163), personeli güçlendirmek için örgütlerin firsat yapısı ve güç yapısı olarak tanımlanan güçlendirme yapılarına sahip olmaları gerektiğini ileri sürmüştür. Kanter, firsat yapısını, çalışanların işılerinde eğitilmelerini ve gelişmelerini sağlayan “iş özellikleri” olarak açıklamıştır. Kanter'e göre firsat yapısı, personel motivasyonunu, verimliliğini, bağlılığını ve işe katılım derecesini önemli ölçüde etkileyen işin özellikleridir. Kanter, güç yapısını, personelin kaynakları seferber etmelerini sağlayan “örgütsel özellikler” olarak açıklamıştır. Özellikle, yapısal gücün üç örgütsel kaynaktan; bilgi, destek ve kaynaklardan geldiğini belirtmiştir. Bilgi, örgütün çalışması ve bireyin işinde başarması için gerekli olan bilgi olarak açıklanır. Kaynaklar, işin etkili bir şekilde görülmesi için gerekli personel, para, zaman, donanım ve malzemelerdir. Destek, personelin yönetim, akran ve diğerlerinden aldığı geribildirim, koçluk ve yardımlardır. Bu örgütsel güçlendirme yapıları, personelin örgütsel hedeflere ulaşmadaki başarısına katkıda bulunmaktadır. Kanter (1977), ayrıca firsat ve güç yapısının birlikte bireysel olarak personelin güçlenme hissini olumlu yönde etkilediğini ve iş etkinliğini artırdığını ileri sürmüştür.

Kanter, güçlendirmenin, belirli güç hatlarından geçtiğini belirtmiştir. Personel, bilgi, destek, kaynak ve firsat hatlarına erişebiliyorsa güç açıktır. Bu "hatlar" mevcut değilse ya da erişilemiyorsa güç kapalıdır ve etkili çalışma mümkün değildir. Bu güç hatları kurum içinde yapısal güçlendirmenin ana kaynaklarıdır. (Greco vd., 2006; Laschinger vd., 2001; 2004). Ayrıca bu güçlendirici yapılara ulaşmak "resmi güç" ve "gayri resmi güç" sistemleri yoluyla kolaylaşmaktadır. Resmi güç, görünürlüğü 
yüksek, inisiyatif alınabilinen, otonomiye olanak sağlayan işlerde bulunur. Gayri resmi güç ise bireyin örgüt içinde, üstleri, çalışma arkadaşları, diğer çalışanlar ve örgüt dışındaki bağlantılar ile iletişim ve iş birliğinden kaynaklanmaktadır (Sürgevil vd., 2013: 5374). Böylece bu güçlendirici yapılar personel üzerinde bireysel olarak birçok olumlu sonuç ortaya çıkarabilirken, örgütsel olarak da birçok olumlu sonuçlar ortaya çıkarabilmektedir.

Yapısal güçlendirme üzerine yapılan çalışmalarda "psikolojik güçlendirme" dikkati çeker (Laschinger vd., 2001; 2003; 2004; 2009; Carless, 2004; Wallach ve Mueller, 2006; DeCicco vd., 2006; O’Brien, 2011; Tolay vd., 2012). Psikolojik güçlendirme en çok çalışılan yapısal güçlendirme sonucudur. Güçlendirme, güçsüzlük oluşturan koşulların belirlenmesi aracılığı ile örgütsel üyeler arasında özyeterlilik algısının artırılması süreci olarak ifade edilmektedir (Conger ve Kanungo, 1988: 474; Spreitzer, 2007: 6). Bu aslında yapısal ve yönetsel uygulamalarla gerçekleştirilecek yapısal güçlendirmenin psikolojik güçlendirmeyle sonuçlanacağına da işaret etmektedir.

Yapısal güçlendirme ile örgüt yapısının fırsat ve kaynaklara ulaşımı sağlayan, yöneticilere güven duyulan, kararlara katılım ile tartışma ortamında çatışmaların azaldığı, problemlerin çözüldüğü bir ortam oluşmaktadır. Böylece çalışanlar inisiyatif alabilmekte, hızlı karar vererek harekete geçebilmekte, işini anlamlı bulabilmektedirler (Meng vd., 2015: 309). Böyle bir ortamda kendini psikolojik olarak güçlendirilmiş algılayan personel daha az tükenmişlik algılamaktadırlar (Laschinger vd., 2003; Meng vd., 2015). Yapısal güçlendirme tükenmişlikle mücadelede, personelin daha etkin bir şekilde karar vermelerini sağlarken ve performansını olumlu yönde etkilemektedir (Jaffery ve Farooq, 2015). İşini anlamlı bulan, örgütsel desteği hisseden ve psikolojik güçlendirilmiş personel işinden daha fazla doyum algilamaktadır (Lautizi vd., 2009; Tolay vd., 2012).

Sorumluluk alma, işiyle ilgili karar verebilme özgürlüğü, yeni şeyler öğrenme şansı gibi iş karakterleri bir firsat oluşturarak, personelin örgütsel bağl1lık düzeylerini olumlu yönde etkilemektedir (Kanter, 1977: 143-145). Aynı zamanda yapısal güçlendirme, örgütte olumlu bir iklim oluşturarak, işe adanmanın gelişmesine katkı sağlayacak örgütsel koşulları oluşturmakta (Laschinger vd., 2009); güçlendirilen ve örgütsel rolünü benimseyen, işin sahibi haline gelen çalışanlar, kendilerini işlerine vererek, işleriyle daha fazla meşgul olmakta ve böylece işlerine adanmaları da beklenmektedir (Kanten, 2012: 33).

Yapısal güçlendirme personelin adalet, ödül, kontrol ve iş yükü gibi algılarını olumlu yönde etkilerken, özerkliğin, kararlara katılımın olduğu iş ortamı işten ayrılma niyetini azaltabilmektedir (Meng vd., 2014). Yapısal güçlendirme, personelin yüksek oranda yenilikçi ve yaratıcı iş performansı 
göstermesine olanak sağlamakta, onların motivasyonunu artırarak daha fazla performans sergilemelerine yol açmaktadır (Laschinger ve Finegan, 2005).

Yapısal güçlendirme, personele kararlara katılım, iş birliğinin, kendini geliştirme firsatı, destek, kaynak ve bilgi paylaşımının sağlandığı ortam oluşturarak onların bilişsel ve duyuşsal olarak güçlendirilmelerini amaçlamaktadır. Böylece karşılaştıkları problemlerde hızlı ve pratik kararlar alabilirler, yaptığı işi sahiplenir ve işlerini anlamlı bularak daha fazla çaba gösterebilirler. Ayrıca işyerinde gerekli eğitimleri alarak kendi alanlarında uzmanlaşabilir, yeni fikirler üretebilir, yaratıcılıklarını geliştirebilir ve üyesi olduğu örgüte güven duyabilirler. Sonuç olarak; yapısal güçlendirme bir yönetim tekniği olarak kullanıldığında birçok olumlu sonucu da beraberinde getirebilecektir. Çünkü yapısal güçlendirme çalışanların işlerine karşı algılarını ve performanslarını olumlu yönde etkilemekle birlikte hem bireysel hem de örgütsel başarılar elde edilmesinde önemli katkılar sağlayabilmektedir.

\section{KAMU YÖNETIMINDE YAPISAL GÜÇLENDİRME}

Güçlendirme uygulamaları öncelikle özel sektör tarafından uygulanmaya başlanmış ve yeni bir yönetim tekniği olarak dikkat çekmiştir. Sonrasında ise farklı ülkelerin farklı reformlarla kamu yönetimlerinde Dünya Bankası, Avrupa Birliğgi, OECD, Birleşmiş Milletler gibi uluslararası örgütlerin de destekleriyle yapısal güçlendirme uygulamalarına yöneldiği görülmüştür. Kamu yönetiminde, hızlı hareket etme, hızlı karar alma, yönetime dinamik ve esnek bir yapı kazandırma, toplumsal taleplerin karşılanmasına yönelik bir yapı oluşturma gibi amaçlar bu reformların ortaya çıkmasını tetiklemiştir (Özer, 2019: 4).

Kamu yönetiminde yapısal güçlendirme uygulamalarının Yeni Kamu Yönetimi anlayışı çerçevesinde, ABD, İngiltere, Kanada, Avustralya, Fransa, İsveç ve Norveç gibi birçok gelişmiş ülkenin reform çalışmalarında, hükümet programlarında ve politikalarında (Pollitt, 1990; Hood, 1991; Gore, 1993; Peters, 1996; Wise, 2002; Kettl, 2005; Matheson, 2007) belirgin olarak yer aldığ1 görülmektedir (aktaran: Moldogaziev, 2013: 158). Örneğin, ABD’de özel sektör uygulamalarının kamu yönetimine aktarılması sürecinde “Amerikan Ulusal Performans Değerlendirme Projesi” gerçekleştirilmiş ve bu kapsamda "personel güçlendirme” bir ilke olarak yer almıştır (Çelik, 2013: 93).

Bununla birlikte, güçlendirme uygulamalarının kamu yönetiminde uygulanmasının zor olacağ 1 yönünde iddialar da mevcuttur (Çuhadar, 2005; Akçakaya, 2010; Alkan, 2010; Fernandez ve Moldogaziev, 2011; 2013; 2015; Demircioğlu, 2018). Bu iddialar hemen hemen kamu yönetimlerinin bütününe genellenebilse de Türk Kamu Yönetimi özelinde incelendiğinde, yapısal güçlendirme 
uygulamalarının önündeki engeller; yasal, örgütsel, kültürel, teknik ve yöneticilerden kaynaklı engeller olarak açıklanabilmektedir (Çuhadar, 2005: 6).

Ancak, Türk Kamu Yönetimi’nde yapısal güçlendirmenin uygulanmasının önündeki engelleri aşmaya yönelik birçok yapısal düzenleme ve reformların gerçekleştirildiği de görülmüştür. Örneğin, reform niteliğinde bir yasal düzenleme olan 5018 sayılı Kamu Mali Yönetimi ve Kontrol Kanunu ile yönetim anlayışında, stratejik planlama, hesap verebilirlik, şeffaflık, performans odaklılık gibi kavramlar öne çıkmıştır.

2002 yılında açıklanan “Acil Eylem Planı” içerisinde, "Herkese Sağlık” başlığı altında, sağlık alanında yürütülecek temel hedefler arasında yapısal güçlendirme uygulamalarına rastlanılmıştır. "Sağlık Bakanlığının idari ve fonksiyonel açıdan yeniden yapılandırılması”, “Tüm kamu kuruluşlarında alt kademelere yetki devri yapılması”, "Sağlık alanında e-dönüşüm projesinin hayata geçirilmesi” gibi hedeflerle yapısal güçlendirmenin; örgütsel yapının ve personelin güçlendirilmesine yönelik uygulamaların gerçekleştirileceği vurgulanmıştır. Diğer bir örnek olarak Sağlıkta Dönüşüm Programı'nda katılımcı yönetim anlayışı, personelin eğitim ve geliştirilmesine fırsat sağlama, karar süreçlerinde etkili bilgiye erişebilirliği artırma, performans değerlendirme ve kaynakların etkili kullanımı gibi yapısal güçlendirme için de kritik konular önemle vurgulanmıştır (Seçtim, 2019: 118120).

Sonuç olarak; kamu yönetiminde yapısal güçlendirmenin önünde engeller olduğu görülse de birçok ülkenin Yeni Kamu Yönetimi anlayışıyla yapısal güçlendirme uygulamalarına yöneldiği görülmüştür. Bununla birlikte Türk Kamu Yönetimi özelinde kapsamlı yasal düzenlemeler tam olarak gerçekleştirilemese bile, BM, OECD, AB gibi uluslararası kuruluşların uygulamaları paralelinde Yeni Kamu Yönetimi anlayışına yöneldiği ve yapısal güçlendirme uygulamalarına yer verildiği görülmüştür.

Kanter'in yapısal güçlendirme teorisi; personele destek, bilgi, kaynak sağlanması ve gelişim fırsatlarına erişimin kolaylaştırılması olarak açıklanabilmektedir. Bununla birlikte örgüt yapısının basık ve esnek bir hale getirilmesi, personelin kararlara katılımı, inisiyatif, sorumluluk almalarının ve iş birliğinin desteklenmesi de gerekmektedir. Bu kapsamda değerlendirildiğinde kamu yönetiminin bürokratik yapısı gereği, yapısal güçlendirmenin özel sektör uygulaması gibi uygulanması zor olabilmektedir. Ancak, çağın gereği olarak kamu kurumlarında yapısal güçlendirme uygulamalarına yönlendiği ve kamu yönetiminin kendi özellikleri çerçevesinde uygulandığı da görülmüştür. 


\section{ÖRGÜTSEL ÖZDEŞLEŞME}

Dünyada yaşanan toplumsal, teknolojik ve çevresel değişimler örgütlerin başarısını derinden etkilemektedir. Bu süreçle birlikte, insan kaynakları örgütün başarısı üzerindeki önemini giderek artırmakta ve örgütlerin insan kaynaklarına olan bakış açılarının da buna bağlı olarak değiştiği görülmektedir. Örgütler artık çalışanların sadece işyerlerini sevmelerini ve sadakat duymalarını değil aynı zamanda çalışanların örgütlerini kendi kimlikleri ile özdeşleştirecek derecede benimsemelerini istemektedirler. Örgüt üyeliğini çalışanların kimliklerinin önemli bir parçası hâline getirmek, onların kendilerini örgütün üyesi olarak tanımlamalarını, aynı zamanda gurur duymalarını sağlamak, örgütlerin uzun vadeli başarılar kazanmalarında kritik bir role sahip olmaktadır (İşcan, 2006: 161). Bu kapsamda örgütlerde özdeşleşmiş çalışanların önemi artmakta; örgütler, özdeşleşmenin sağlanmasına giderek daha fazla önem vermektedirler.

İnsanlar kendilerini genellikle belirli bir grubun üyesi olarak tanımlamaktadır. Bu sosyal kimlikler yaygın olarak bir ülkenin, cinsiyetin, ırkın, spor takımının veya örgütün parçası olabilmektedir. Ancak grupların hayatta kalabilmeleri de üyelerin varlığına bağlıdır. Tajfel (1972: 292) sosyal kimliği, bireyin kendisini üyeleriyle arasında duygusal bağ hissettiği ve benzer değerleri paylaştığı belirli grubun üyesi olarak ifade etmesi şeklinde tanımlamaktadır. Örgütsel özdeşleşme (organizational identification) esasen sosyal kimliğin önemli bir biçimidir ve genellikle bireyin benlik duygusunun önemli bir parçasını (Mael ve Ashforth, 1992: 104) içermektedir. Örgütsel özdeşleme, bireyler ve çalıştıkları örgüt arasındaki ilişkiyi açıklamanın da bir yoludur. Örgütsel özdeşleşmenin örgütsel yaşamda önemli bir faktör olduğu birçok kez kanıtlanmıştır. Bu alanda yapılan araştırmalar, kişilerin kendilerini güçlü bir şekilde örgütleriyle tanımlayan çalışanların, çalıştıkları örgüte karşı daha olumlu tutum ve davranışlar sergilediğini göstermekte; çalışan ile örgüt arasındaki bağı ve yönetimin çalışanların örgütle ilgili kararlara ilgi duymalarını nasıl teşvik ettiğini açıklamaya çalışmaktadır. Örgütsel özdeşleşme ile ilgili alanyazın, özdeşleşmenin çalışanın sosyal kimliklerinin bir parçası olan örgütsel kimliğin bir sonucu olarak geliştiğini belirtmektedir. Ayrıca özdeşleşmenin örgüt üyelerini örgütsel kararlara katılımını ve örgütsel amaçlara göre davranmalarını teşvik ettiği, örgütsel davranış şekillerini benimsemelerini (Tompkins ve Cheney, 1985) dolayısıyla örgütsel verimliliğe katkıda bulunmalarını sağladığını göstermektedir.

Özdeşleşme düzeyi bazı durumlarda büyük önem kazanmaktadır. Örneğin çevre koşulları örgütün varlığını sürdürmesini güçleştirdiği durumlarda, özdeşleşmenin gerçekleştirilmesi zor olabilmektedir. Bu durumda örgütsel varlığın devamı için özdeşleşme düzeyi yüksek insan kaynağına olan ihtiyaç da fazla olmaktadır (Polat ve Meydan, 2010: 150). Böylece örgütüyle özdeşleşmiş çalışanlar daha verimli 
olabilmekte; bu da örgütün başarısını etkilemesi açısından örgütsel özdeşleşmenin önemini ortaya koymaktadir.

Örgütsel özdeşleşmenin önemi, bir örgütte karar vericilerin o örgütün çıkarlarını en iyi destekleyen alternatifi seçmek istediğinde ortaya çıkmaktadır. Bu aşamada bireyin rolü, ortak çıkarların sağlanması ve olumlu sonuçlara odaklanma da belirleyici unsurlardır. Örgütüyle özdeşleşmeyi geliştiren bireyler, örgütün çıkarlarını kendi kişisel değer sistemlerine dâhil ederek daha fazla olumlu çıktılar sağlamaktadırlar. Karar vericiler, bireylerin yarattığı bu farkı anladığında, dolayısıyla özdeşleme düzeyinin artırılmasının ve ölçülmesinin önemini de anlayabilmektedirler (Cheney ve Tompkins, 1987: 2).

Örgütsel özdeşleşme çalışanlar için önemlidir, çünkü bu süreç bireylerin kendilerini tanımlamaları ile ilgili bir süreçtir, başkalarıyla bu tanımla iletişim kurarlar, iş yaşamları ve diğer yaşamlarındaki süreçlere yön verirler (Ashforth vd., 2008: 334). Örgütsel özdeşleşme örgütler için de önemlidir çünkü örgütsel özdeşleşme kişisel çıkarlar ve davranışlar ile örgütün çıkarlarını sağlayacak davranışlar arasında uyum sağlayarak, üyeleri olumlu örgütsel vatandaşlık davranışları göstermeleri yönünde güdülemekte, böylece olumlu örgütsel çıktılar elde edilebilmektedir (Yanar, 2005: 11).

Örgütsel özdeşleşme, birey ve örgüt açısından birçok yarar sağlamaktadır. Personelin örgütle özdeşleşmesi, yaptığı işten keyif almasını, işini anlamlı bulmasını sağlamaktadır. Bu da personelin işten ayrılma niyetini azaltarak, bağlılığını artırmaktadır. Örgütü ile özdeşleşen çalışanlar, örgütün amaçları ile kendi amaçlarını bir görerek, örgüte daha fazla katkı sağlamaktadırlar. Ayrıca özdeşleşme, personeli örgüt yararına gönüllü davranışlar sergilemeye yöneltmektedir (Zencirkıran ve Keser, 2018: 293). Günümüz çevre koşulları dikkate alındığında bu durumlar örgütlerin başarısında örgütsel özdeşleşmenin önemini daha da ön plana çıkarmaktadır.

\section{YAȘAM DOYUMU}

İnsanların yaşamlarını sürdürmeleri ve yaşadığı hayatı anlamlı bulmaları için yaşamlarından doyum almaları gerekmektedir. Yıllarca psikoloji alanında bireyin yaşamındaki mutsuzluk ve stres gibi olumsuzluklara odaklanılmasına rağmen pozitif öznel iyi oluş göz ardı edilmiştir. Son yıllarda davranış ve sosyal bilimciler tarafından yapılan teorik ve ampirik çalışmalarla bu durumun telafi edildiği ve yaşam doyumuna yönelik ilginin de arttığı görülmektedir (Diener, 1984: 542).

Bireyin mutluluğuna ve yaşam doyumuna ilişkin bilimsel çalışmaların hümanist yaklaşımlar temelinde felsefeye yönelmesi, 20. yy. başlarında pozitif psikoloji paradigmasının ortaya çıkmasını ve gelişmesini sağlamıştır. Araştırmacılar "Yaşamı daha iyi yapan, yaşamayı değerli kılan şeyler nelerdir?", "Yaşamın anlamı ve amacı nedir?” gibi sorulardan yola çıkarak, geçmişte yalnızca bireyin 
olumsuz durumlarına odaklanan bilimsel yaklaşımlara farklı bir bakış açısı önermişledir (Seligman, 2007: 278). Bireyin psikopatolojik sorunları yerine onun güçlü yönlerine odaklanan ve bu yönleri geliştirerek mutluluğun artırılmasını amaçlayan pozitif paradigma bu süreçte geliştirilmiştir (Şimşek ve Aktaş, 2014: 149).

Yaşam doyumu, pozitif psikoloji paradigmasının en önemli yapı taşlarından birisidir. Yaşam doyumuna ilişkin çalışmalar, bireyin zayıf yönlerinin yerine güçlü yönlerini tanımlamayı ve geliştirmeyi amaçlamaktadır (Proctor vd., 2009). Bununla birlikte yaşam doyumunun sağlık, başarı, çalışma yaşamında yüksek performans ve kazanç, örgütsel uyum sağlama gibi iş ve iş dişı olumlu sonuçlara yol açması, bu kavrama yönelik yapılan bilimsel çalışmaların da artmasını sağlamıştır (Doğan ve Şahin, 2015: 133).

Bireyin beklentilerinin, varolan durum ile karşılaştırılması sonucunda ortaya çıkan yaşam doyumu, genel olarak bireyin bütün yaşamını ve bu yaşamın farklı boyutlarını kapsamaktadır. Günlük yaşamdan mutluluk duymak, hayatı anlamlı bulmak, belirlenen hedeflere ulaşma konusunda uyumluluk gösterebilmek, olumlu bireysel kimlik, fiziksel açıdan kendini iyi hissetmek, iktisadi güvenlik ve sosyal ilişkiler yaşam doyumu kapsamı içerisinde yer almaktadır (Kuzulu vd., 2013: 93).

Yaşam doyumu üzerinde genetik olarak belirlenmiş mutluluk alanının \% 50, çevresel etkenlerin \% 10 ve mutlulukla ilgili faaliyetlerin \% 40 etkisi olduğu belirtilmektedir (Lyubomirsky vd., 2005). Bireyin kişilik özellikleri ve olumlu ruh halinin büyük oranda etkili olduğu belirtilmekle birlikte; evlilik, aile, iş, sosyal çevre gibi yaşamın her alanının yaşam doyumu algısıyla ilişkili olduğu da ifade edilebilir.

Yaşam doyumunun objesi yaşamın tüm alanlarıdır. Yaşam alanlarını ise iş ve iş dışı yaşam alanları olarak ayırmak mümkündür. Son yıllarda insanların büyük bir kısmı yaşamlarının önemli bir kısmını iş ortamlarında geçirmekte ve iş yaşamı bireyin iş doyumu elde etmesinin yanı sıra yaşamından doyum sağlamasında da önemli bir etken olabilmektedir. İş yaşamının bireyin yaşam doyumu üzerindeki etkileri dikkate alındığında, bugünün örgüt yönetimlerinin bu konuya daha fazla önem vermeleri hem bireysel hem de örgütsel olumlu çıktılara yol açabilmesi sebebiyle önem kazanmaktadır.

\section{YAPISAL GÜÇLENDİRMENIN ÖRGÜTSEL ÖZDEŞLEŞME VE YAŞAM DOYUMU ÜZERINDEKİ ETKILERİ ALAN ARAŞTIRMASI}

$\mathrm{Bu}$ bölümde öncelikle araştırma hakkında açıklamalar yapılmış ardından elde edilen bulgulara yer verilmiştir. Bölüm elde edilen bulguların tartışılmasıyla sonlandırılmıştır.

\section{Araştırmanın Konusu ve Önemi}

Yapısal güçlendirmenin kuramsal temellerini atan Kanter (1977), personeli güçlendirmek için örgütlerin fırsat yapısı ve güç yapısı olarak tanımlanan güçlendirme yapılarına sahip olmaları 
gerektiğini ifade etmektedir. Fırsat yapısı, personelin eğitim ve gelişme firsatları elde etmelerini sağlayan, ayrıca onların motivasyonunu, verimliliğini, bağlılığını ve işe katılım derecesini önemli ölçüde etkileyen işin özellikleridir. Güç yapısı ise, personelin kaynakları seferber etmelerini sağlayan; bilgi, destek ve kaynaklardan gelen örgütsel özelliklerdir. Güçlendirme uygulamalarına uygun örgüt yapıları personelin yasal pozisyonundan kaynaklanan resmi güç ve personelin üstleri, astları, akranları ve diğer paydaşlarla kurduğu ilişkiler, iletişim ve iş birliklerinden oluşmaktadır. Güçlendirici yapılar ve güçlendirme uygulamalarına ulaşım sağlayan örgüt yapıları, birlikte personelin güçlenme hissini olumlu yönde etkilemektedir. Böylece personelin iş etkinliğinin artması beklenmektedir. Ayrıca personel kendini güçlenmiş olarak algıladığında stres ve tükenmişlik duygusu azalmakta, işleri üzerinde kontrol ve özerklik hissi duymakta, örgütüne daha fazla bağlllık ve özdeşleşmiş hissedebilmektedirler (Kanter, 1977: 129-163). Güçlendirilmiş personel hem işleri ve örgütleri hem de kendileri ile ilgili daha iyi duygu ve düşüncelere sahip olmaktadır (Lautizi vd., 2009; Erkul vd., 2018). Birey örgütüne karşı olumlu duygular hissederken örgütüyle ortak özelliklerini de pekiştirmektedir. Bununla birlikte yapısal güçlendirme, bireyin kendisini güçsüz hissettiren unsurları ortadan kalkmasını sağlarken, öz yeterlilik algısını da olumlu yönde etkilemektedir. Böylece bireyin yüksek düzeyde örgütüyle özdeşleşmesi beklenmektedir.

Yapısal güçlendirme; bireylerin işlerinde bilgi, destek, firsat ve kaynaklara ulaşabildiği, yöneticilere ve örgütüne güven duyduğu, kararlara katıldığı problemlerin çözüldüğü bir ortam oluşturmayı ifade etmektedir (Meng vd., 2015). Böyle bir ortamda ise bireyler inisiyatif alabilirken aynı zamanda öz yeterlilik duygusu gelişmekte, işini anlamlı bulabilmekte ve güçsüzlük veren etkenler giderilmektedir. Sonuç olarak; olumlu ruh hali gelişmekte ve böylece yapısal güçlendirmenin genel yaşam doyumunu olumlu yönde etkilemesi beklenmektedir.

Alan araştırmasının konusunu; kamu kurumlarında yapısal güçlendirmenin personelin örgütsel özdeşleşme ve yaşam doyumu üzerindeki etkileri oluşturmaktadır. Alanyazın incelendiğinde; yapısal güçlendirme ve örgütsel özdeşleşme kavramlarının birlikte incelendiği bazı çalışmalar olduğu görülmüştür. Ancak yapısal güçlendirme, örgütsel özdeşleşme ve yaşam doyumu kavramlarının birlikte ele alındığı bir çalışma saptanamamıştır. Bu kavramların hepsinin bir arada incelendiği bir çalışmanın saptanamaması, araştırmanın alana sağlayacağı katkı açısından önem taşımaktadır.

Yapılan alanyazın taraması sonucunda yapısal güçlendirmenin bireysel olarak personelin yaşam doyumu elde etmesini, örgütsel olarak örgütsel özdeşleşmenin gerçekleşmesini artıracağ görülmüştür. Örgütsel başarı elde edilebilmesinde de önemli unsurlar olarak görülen bu kavramların incelenmesinin, yönetim alanına katkı sağlayabileceği düşünülmektedir. 


\section{Araştırmanın Amacı}

Araştırmanın amacını; kamu kurumlarında yapısal güçlendirme uygulamalarının personel üzerindeki örgütsel ve bireysel etkilerini incelemek, elde edilen verilerle kamu kurumlarının yönetimlerine, yönetsel kapasitenin artırılmasına yönelik öneriler sunmak oluşturmaktadır. Bu doğrultuda kamu kurumlarına yönelik geliştirilen yapısal güçlendirme ölçeğinin kamu kurumu personelinde test edilmesi ve yapısal güçlendirme uygulamalarının personelinin örgütsel özdeşleşme ve yaşam doyumu algısı üzerindeki etkisinin incelenmesi amaçlanmıştır. Kamu kurumlarında kurumsallaşma düzeyi, personele sağlanan örgütsel destek, kaynaklar, insan kaynakları politikaları ile eğitim ve geliştirme firsatlarının; personelin örgütsel özdeşleşme ve bu kapsamda sadakat ve üyelik-benzerlik düzeyleri yanı sıra, yaşam doyumu düzeyleri üzerindeki etkilerinin incelenmesi hedeflenmiştir. Bu sayede kamu kurumlarındaki uygulamaların personel üzerindeki etkileri test edilerek, kamu kurumlarına yönelik geliştirilen ölçeğin kullanıldığı bu model vasıtasıyla alanyazına katkı sağlanması amaçlanmıştır.

\section{Araştırmanın Evreni ve Örneklemi}

Araştırmanın evrenini kamu kurumlarında çalışan personel oluşturmaktadır. Konu gereği kamu personeline ulaşılması gerektiğinden, Trakya Üniversiteler Birliği'ne bağlı olarak faaliyet gösteren hastanelerde görev yapmakta olan hemşire, laborant, radyoloji teknikeri, acil tıp teknisyeni gibi unvanlara sahip çalışanlara ulaşılmıştır. Örneklem homojen olması açısından hekim dışı personel ile sınırlandırılmış bu kapsamda benzer statülerde çalışanlar araştırmaya dâhil edilmiştir. Örnekleme yöntemi olarak kolayda örnekleme yöntemi kullanılmıştır. Hastanelerden alınan izinler doğrultusunda teslim edilen 1.200 anket formundan geriye dönen 550 adet (\% 46) anket formunun 538 adedi (\% 45) değerlendirme kapsamına alınmıştır. Araştırmaya katılan katılımııların anket formlarındaki ifadeleri gerçek durumu yansıttığı ve doğru biçimde cevapladıkları varsayılmaktadır.

Araştırmanın modeli, alanyazındaki çalışmalarda kabul gören değişkenler arası ilişsilerin test edilmesine yönelik hazırlanmıştır. Araştırma modelindeki genel ilişkisel yaklaşımlar; bağımsız değişkenler (örgütsel destek, kaynaklar, eğitim ve geliştirme, kurumsallaşma ve insan kaynakları politikaları) ile bağımlı değişkenler (yaşam doyumu, sadakat, benzerlik- üyelik) arasında bir ilişki bulunduğunu göstermektedir. 


\section{Araştırmanın Modeli ve Hipotezleri}

YAPISAL GÜÇLENDİRME

ÖRGÜTSEL ÖZDEŞLEŞME

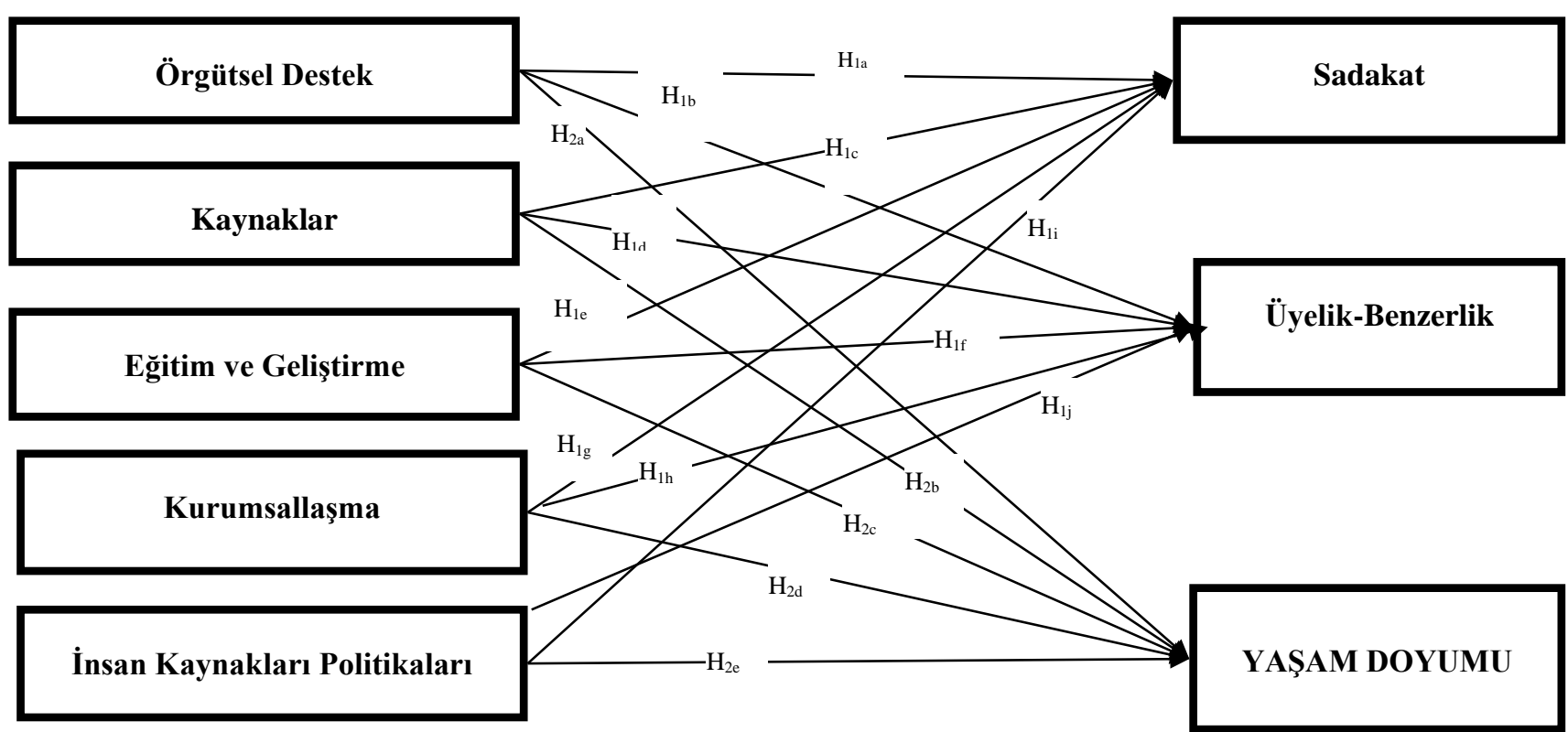

Araştırmanın amacı ve modeli doğrultusunda; değişkenler arasındaki ilişkilerin test edilmesine yönelik araştırmanın ana hipotezleri ve alt hipotezleri şu şekilde geliştirilmiştir:

H1: Yapısal güçlendirme uygulamaları kamu kurumlarında personelin örgütsel özdeşleşme düzeylerini anlamlı olarak etkilemektedir.

H1a: Örgütsel destek, kamu kurumlarında personelin sadakat düzeylerini anlamlı olarak etkilemektedir.

H1b: Örgütsel destek, kamu kurumlarında personelin benzerlik-üyelik düzeylerini anlamlı olarak etkilemektedir.

H1c: Kaynaklar, kamu kurumlarında personelin sadakat düzeylerini anlamlı olarak etkilemektedir.

H1d: Kaynaklar, kamu kurumlarında personelin benzerlik-üyelik düzeylerini anlamlı olarak etkilemektedir.

H1e: Eğitim ve geliştirme, kamu kurumlarında personelin sadakat düzeylerini anlamlı olarak etkilemektedir.

H1f: Eğitim ve geliştirme, kamu kurumlarında personelin benzerlik-üyelik düzeylerini anlamlı olarak etkilemektedir.

H1g: Kurumsallaşma, kamu kurumlarında personelin sadakat düzeylerini anlamlı olarak etkilemektedir.

H1h: Kurumsallaşma, kamu kurumlarında personelin benzerlik-üyelik düzeylerini anlamlı olarak etkilemektedir.

H1i: İnsan kaynakları politikaları, kamu kurumlarında personelin sadakat düzeylerini anlamlı olarak etkilemektedir. 
$\mathbf{H}_{\mathbf{1 j}}$ : İnsan kaynakları politikaları, kamu kurumlarında personelin benzerlik- üyelik düzeylerini anlamlı olarak etkilemektedir.

H2: Yapısal güçlendirme uygulamaları kamu kurumlarında personelin yaşam doyumu düzeylerini anlamlı olarak etkilemektedir.

$\mathbf{H}_{\text {2a: }}$ Örgütsel destek, kamu kurumlarında personelin yaşam doyumu düzeylerini anlamlı olarak etkilemektedir.

$\mathbf{H}_{2 \mathbf{b}}$ : Kaynaklar, kamu kurumlarında personelin yaşam doyumu düzeylerini anlamlı olarak etkilemektedir.

H2c: Eğitim ve geliştirme, kamu kurumlarında personelin yaşam doyumu düzeylerini anlamlı olarak etkilemektedir.

$\mathbf{H}_{2 \mathrm{~d}}$ : Kurumsallaşma, kamu kurumlarında personelin yaşam doyumu düzeylerini anlamlı olarak etkilemektedir.

H2e: İnsan kaynakları politikaları, kamu kurumlarında personelin yaşam doyumu düzeylerini anlamlı olarak etkilemektedir.

\section{Araştırmanın Yöntemi}

Araştırma, betimsel araştırma yöntemi kullanılarak yapılmış; olgular arasındaki neden-sonuç ilişkisi çerçevesinde kamu kurumlarında yapısal güçlendirmenin personelin örgütsel özdeşleşme ve yaşam doyumu üzerindeki etkileri betimlenmeye ve açıklanmaya çalışılmıştır. Araştırmada nicel veriler kullanılmış bu kapsamda veriler anket tekniği ile elde edilmiştir.

Araştırma kapsamında katılımcılardan elde edilen veriler SPSS 22 ve Smart PLS v3.2.7 programlarından yararlanılarak analiz edilmiştir. Tanımlayıcı istatistikler, güvenilirlik analizleri, açıklayıcı faktör analizleri ve korelasyon analizlerinde SPSS 22 programı kullanılmış, Smart PLS programı ile kısmi en küçük kareler-yapısal eşitlik modeli, araştırma modeli ve hipotezleri test edilmiştir.

\section{Yararlanılan Ölçekler}

Kullanılan ölçekler alanyazın incelenerek elde edilmiştir. Elde edilen ölçekler Türkçe geçerlilik ve güvenilirlik çalışmaları yapılan ölçeklerdir. Ölçek maddelerinin yer aldığı anket formlarında Likert tipi 5'li metrik ifadelere yer verilmiştir. Buna göre "1- kesinlikle katılmıyorum", "2- katılmıyorum”, "3- ne katılıyorum ne katılmıyorum", "4- kat1lıyorum" ve "5- kesinlikle katıliyorum" olarak derecelendirilmiştir.

Yapısal güçlendirme ölçeğinde; örgütsel destek, kurumsallaşma, kaynaklar, insan kaynakları politikaları ile eğitim ve geliştirme olmak üzere 5 boyutlu ve 27 ifadeli "Kamu Kurumlarına Yönelik Yapısal Güçlendirme Ölçeği” kullanılmıştır. Ölçek kapsamında "Bu kurumun tüm birimlerinde nitelikli personel istihdam edilmektedir", "Bu kurum çalışanları açısından sağlıklı bir iş ortamı 
yapılandırmaya önem vermektedir" ve "Bu kurumda çalışanların inisiyatif almaları desteklenmektedir" gibi ifadeler bulunmaktadır.

Örgütsel özdeşleşme ölçeğinde, Cheney’in (1982) geliştirdiği “Örgütsel Özdeşleşme Ölçeğii”nin (Organizational Identification Questionnaire-OIQ), Johnson ve arkadaşları (1999) tarafından sadeleştirilmiş versiyonu olan; 23 ifade ve sadakat, üyelik ve benzerlik olmak üzere 3 boyuttan oluşan ölçek kullanılmıştır. Örgütsel özdeşleşme ölçeğinin Türkçe uyarlaması Kanten'in (2012) çalışmasından alınmıştır. Ölçek kapsamında "Bu kurumdakiler aynı amaç doğrultusunda çalışıyorlar", "Dışarıdaki kişilerin çalıştığım kurumu eleştirmelerine sinirlenirim" ve "Bu kurumun geleceğini önemsiyorum” gibi ifadelere yer verilmiştir.

Yaşam doyumu ölçeğinde ise Diener ve arkadaşları (1985) tarafından geliştirilmiş olan, 5 ifadeli ve tek boyutlu "Yasam Doyumu Ölçeği”" (Satisfaction with Life Scale) kullanılmıştır. Ölçeğin Türkçeye uyarlaması, Dağlı ve Baysal (2016) tarafından 5'li Likert yapısında gerçekleştirilmiştir. Ölçek kapsamında "Yaşam koşullarımın mükemmel olduğunu düşünüyorum”, "Şimdiye kadar hayatta istediğim önemli şeylere sahip olduğumu düşünüyorum" ve "Genel olarak hayatımdan memnunum" gibi ifadeler kullanılmıştır.

\section{Araştırma Bulguları}

Bu bölümde araştırma bulguları; demografik bulgular, güvenilirlik ve faktör analizine ilişkin bulgular, korelasyon analizine ilişkin bulgular, ölçüm modeline ilişkin bulgular, fark testlerine ilişkin bulgular ve yapısal modele ilişkin bulgular çerçevesinde değerlendirilmiştir.

\section{Demografik Bulgular}

Araştırmaya katılan 538 katılımcıya ait demografik özellikler; cinsiyet, yaş, mezuniyet, görev, çalışma süreleri ve toplam çalışma süreleri olarak değerlendirilmiştir. Katılımcılara ait demografik özellikler şu şekilde gösterilmektedir:

Tablo 1. Katılımcıların Demografik Durumuna İlişkin Frekans Dağılımı

\begin{tabular}{|c|c|c|c|c|c|c|c|c|}
\hline Cinsiyet & Frekans & $(\%)$ & Yaş & Frekans & $(\%)$ & Çalışma Süresi & Frekans & $(\%)$ \\
\hline Kadın & 360 & 66,9 & $18-25$ & 140 & 26,0 & 1 yıldan az & 96 & 17,8 \\
\hline Erkek & 178 & 33,1 & $26-41$ & 339 & 63,0 & $1-5$ yil & 196 & 36,4 \\
\hline Toplam & 538 & 100 & $42-49$ & 48 & 8,9 & $6-10$ y1l & 142 & 26,4 \\
\hline \multirow{2}{*}{ Görev } & \multirow{2}{*}{ Frekans } & \multirow{2}{*}{$\%$} & $50+$ & 11 & 2,0 & $11-15$ y1l & 70 & 13,0 \\
\hline & & & Toplam & 538 & 100 & $16+$ & 34 & 6,3 \\
\hline Hemşire & 321 & 59,7 & $\begin{array}{l}\text { Eğitim } \\
\text { Düzeyi }\end{array}$ & Frekans & $\%$ & Toplam & 538 & 100 \\
\hline
\end{tabular}




\begin{tabular}{|l|c|c|l|c|c|l|c|c|}
\hline $\begin{array}{l}\text { Sağlık Memuru / } \\
\text { Teknikeri }\end{array}$ & 86 & 16,0 & Lise & 65 & 12,1 & $\begin{array}{c}\text { Toplam } \\
\text { Çalışma Süres }\end{array}$ & Frekans & $(\%)$ \\
\hline Radyoloji Teknk & 29 & 5,4 & Ön lisans & 121 & 22,5 & 1 yılldan az & 39 & 7,2 \\
\hline Acil Tıp Teknk. & 54 & 10,0 & Lisans & 283 & 52,6 & $1-5$ yıl & 168 & 31,2 \\
\hline Laborant & 48 & 8,9 & Lisansüstü & 69 & 12,8 & $6-10$ yıl & 131 & 24,3 \\
\hline Toplam & 538 & 100 & Toplam & 538 & 100 & $11-15$ yıl & 113 & 21,0 \\
\hline & & & & $16+$ & 87 & 16,2 \\
\cline { 5 - 9 } & & & & Toplam & 538 & 100 \\
\hline
\end{tabular}

Araştırmaya katılan katılımcıların tamamı demografi sorularını cevaplandırmıştır. Katılımcıların büyük çoğunluğunu; kadınlar (\% 66,9), 26-41 yaş aralığındakiler (\% 63), Lisans mezunları (\% 52,6) ve hemşireler (\% 59,7) oluşturmuştur. Ayrıca katılımcıların meslekte çalışma süresi 1-5 yıl olanlar \% 31,2’sini oluştururken kurumda 1-5 y1ldır çalışanların oranı \% 36,4 olduğu görülmüştür.

Araştırmanın hastanelerde gerçekleştirilmiş olması katılımcılarda, kadın ve hemşirelerin oranını artırdığı, ayrıca araştırmanın gerçekleştirildiği hastanelerin faaliyet sürelerinin çok uzun olmamasının da çalışma sürelerini etkilediği düşünülmektedir.

\section{Güvenilirlik ve faktör analizlerine ilişkin bulgular}

Yapısal güçlendirme, örgütsel özdeşleşme ve yaşam doyumu değişkenlerine ait verilere, kullanılan ölçeklerin yapı geçerliliğini sağlamak amacıyla açıklayıcı faktör analizi uygulanmış ve Varimaks döndürme yöntemi kullanılmıştır. Temel bileşenler analizinde gerçekleştirilen Kaiser-Meyer-Olkin (KMO) testleri ve Barlett testlerine ilişkin bulgular ile ölçeklerin genel iç tutarlılık katsayıları Tablo 2'de gösterilmektedir.

Tablo 2. Ölçeklerin KMO, Barlett ve Güvenilirlik Test Değerleri

\begin{tabular}{|c|c|c|c|c|}
\hline Ölçekler & KMO Değerleri & Barlett Değerleri & $\begin{array}{c}\text { Barlett } \\
\text { Anlamlılık }\end{array}$ & $\begin{array}{c}\text { Genel iç Tutarlılık } \\
\text { (Cronbach's Alpha) }\end{array}$ \\
\hline Yapısal Güçlendirme &, 938 & 8047,411 &, 000 &, 942 \\
\hline Yaşam Doyumu &, 752 & 811,170 &, 000 &, 783 \\
\hline Örgütsel Özdeşleşme &, 902 & 2302,691 &, 000 &, 870 \\
\hline
\end{tabular}

KMO değerleri örneklemin faktör analizi için yeterli olduğunu; Barlett testi değerleri ise verilerin normal dağılıma sahip olduğunu göstermektedir. Yapısal güçlendirme, örgütsel özdeşleşme ve yaşam doyumu ölçeklerine ait verilerin açıklayıcı faktör analizine sokulması ve Varimaks döndürülmesi sonucunda faktör yükleri 0.50'nin altında kalan maddeler analiz kapsamından çıkarılmıştır. Açıklayıcı 
faktör analizi sonrası kalan maddeler; 27 ifadeden oluşan yapısal güçlendirme ölçeğinden 25 madde, 23 ifadeden oluşan örgütsel özdeşleşme ölçeğinden 11 madde ve 5 ifadeden oluşan yaşam doyumu ölçeğinden ise 5 madde ile analizlere devam edilmiştir.

Faktör analizi sonucunda yapısal güçlendirme ölçeğinin teoriye uygun bir yapıyı ölçtüğü ve yapı geçerliliğini sağladığı görülmüştür. Yapısal güçlendirme ölçeğinin faktör analizi sonuçları Tablo 3'de ve ölçeğin değişken ortalamaları, standart sapma, faktör ortalamaları Tablo 4'de gösterilmektedir.

Tablo 3. Yapısal Güçlendirme Ölçeği Döndürülmüş Faktör Yükleri

\begin{tabular}{|c|c|c|c|c|c|}
\hline Ölçek Maddeleri & $\begin{array}{r}\begin{array}{r}\text { Örgütsel } \\
\text { Destek }\end{array} \\
\end{array}$ & Kaynaklr & $\begin{array}{l}\text { Eğitim \& } \\
\text { Geliştirme }\end{array}$ & $\begin{array}{l}\text { Kurumsal } \\
\text { laşma }\end{array}$ & İKP \\
\hline 1. Bu kurumda çalışanların inisiyatif almaları desteklenmektedir. & 0,636 & & & & \\
\hline 2. Bu kurumda çalışanların yeni fikirler geliştirmeleri desteklenmektedir. & 0,804 & & & & \\
\hline 3. Bu kurumda çözüm odaklı bakış açısına önem verilmektedir. & 0,832 & & & & \\
\hline 4. Bu kurumda yöneticilerin liderlik rolleri üstlenmeleri beklenmektedir. & 0,886 & & & & \\
\hline 5. Bu kurum çalışanlarını destekleyen politikalar uygulamaktadır. & 0,853 & & & & \\
\hline 6. Bu kurumda çalışanların bilgi ve becerilerini geliştirmeleri desteklenmektedir. & 0,784 & & & & \\
\hline $\begin{array}{l}\text { 8. Bu kurum çalışanlarına iş süreçlerinde yeterli düzeyde teknolojik araç-gereç } \\
\text { sağlamaktadır. }\end{array}$ & & 0,793 & & & \\
\hline $\begin{array}{l}\text { 10. Bu kurum çalışanları açısından sağlıklı bir iş ortam yapılandırmaya önem } \\
\text { vermektedir. }\end{array}$ & & 0,846 & & & \\
\hline $\begin{array}{l}\text { 11. Bu kurumda çalışanların ihtiyaç duydukları kaynaklara ulaşmalarına firsat } \\
\text { verilmektedir. }\end{array}$ & & 0,851 & & & \\
\hline 12. Bu kurumda çalışanların hizmetiçi eğitimlere katılmalarına önem verilmektedir. & & & 0,711 & & \\
\hline 13. Bu kurumda çalışanların çeşitli eğitim programlarına katılmaları desteklenmektedir. & & & 0,763 & & \\
\hline 14. Bu kurum çalışanların talep etmesi halinde eğitim programları düzenlemektedir. & & & 0,852 & & \\
\hline 15. Bu kurumda çalışanların mesleki gelişimlerine önem verilmektedir. & & & 0,770 & & \\
\hline 16. Bu kurumda ihtiyaç duyulması durumunda gereken eğitimler düzenlenmektedir. & & & 0,810 & & \\
\hline 18. Bu kurumun misyonu ve vizyonu belirgindir. & & & & 0,716 & \\
\hline 19. Bu kurum hizmet kalitesinin sağlanmasına önem vermektedir. & & & & 0,792 & \\
\hline 20. Bu kurumun tüm birimlerinde nitelikli personel istihdam edilmektedir. & & & & 0,842 & \\
\hline 21. Bu kurum iş süreçlerinde etkinliğin sağlanmasına önem vermektedir. & & & & 0,836 & \\
\hline 23. Bu kurum başarılı çalışanların ödüllendirilmesine önem vermektedir. & & & & & 0,811 \\
\hline 24. Bu kurumda terfi politikaları etkili bir şekilde yürütülmektedir. & & & & & 0,852 \\
\hline 25. Bu kurumda politika ve prosedürler adaletli bir şekilde yürütülmektedir. & & & & & 0,868 \\
\hline 26. Bu kurumda iş süreçlerinde şeffaflığın sağlanmasına önem verilmektedir. & & & & & 0,828 \\
\hline 27. Bu kurumda çalışanlar için belirlenmiş açık performans kriterleri mevcuttur. & & & & & 0,758 \\
\hline İç Tutarlılık Katsayıları (Cronbach’s Alpha) &, 887 & ,836 &, 839 &, 857 & ,882 \\
\hline Hesaplanan Genel İç Tutarlılık Katsayısı & & &, 942 & & \\
\hline Açıklanan Varyanslar & 15,253 & 15,112 & 14,164 & 11,156 & 11,015 \\
\hline
\end{tabular}

Faktör analizleri sonucunda oluşan faktörler, faktör yükleri, değişken ortalamaları, faktör (boyut) ortalamaları, açıklanan varyanslar ve hesaplanan iç tutarlılık katsayılarına ilişkin bulgular sırasıyla şu şekilde özetlenebilir: 
Yapısal güçlendirme ölçek maddelerinin faktör analizine sokulması sonucunda 5 faktörlü bir yapı elde edilmiştir. Oluşan faktörler toplam varyansın \% 67'sini açıklamaktadır. Birinci faktör örgütsel desteğin açıkladığı varyans oranı \% 15, ikinci faktör kaynakların açıkladığı varyans oranı \% 15 , üçüncü faktör eğitim-geliştirmenin açıkladığı varyans oranı \% 14, dördüncü faktör kurumsallaşmanın açıkladığg varyans oranı \% 11 ve beşinci faktör insan kaynakları politikalarının açıkladığı varyans oranı \% 11 olarak saptanmıştır.

\section{Tablo 4. Yapısal Güçlendirme Ölçeği Değişken Ortalamaları}

\begin{tabular}{|c|c|c|c|c|}
\hline Faktör & Ölçek Maddeleri & $\begin{array}{l}\text { Değişken } \\
\text { Ortalama }\end{array}$ & $\begin{array}{l}\text { Standart } \\
\text { Sapma }\end{array}$ & $\begin{array}{l}\text { Faktör } \\
\text { Ortalama }\end{array}$ \\
\hline \multirow{6}{*}{ 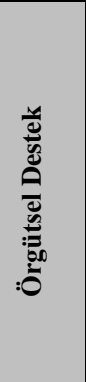 } & 1. Bu kurumda çalışanların inisiyatif almaları desteklenmektedir. & 2,9572 & 1,06232 & \multirow{6}{*}{2,8538} \\
\hline & 2. Bu kurumda çalışanların yeni fikirler geliştirmeleri desteklenmektedir. & 2,8532 & 1,06178 & \\
\hline & 3. Bu kurumda çözüm odaklı bakış açısına önem verilmektedir. & 2,8123 & 1,09853 & \\
\hline & 4. Bu kurumda yöneticilerin liderlik rolleri üstlenmeleri beklenmektedir. & 2,8866 & 1,04470 & \\
\hline & 5. Bu kurum çalışanlarını destekleyen politikalar uygulamaktadır. & 2,7788 & 1,01266 & \\
\hline & 6. Bu kurumda personelin bilgi ve becerilerini geliştirmeleri desteklenmektedir. & 2,8346 & 1,01045 & \\
\hline \multirow{4}{*}{ 齐 } & $\begin{array}{l}\text { 8. Bu kurum çalışanlarına iş süreçlerinde yeterli düzeyde teknolojik araç-gereç } \\
\text { sağlamaktadır. }\end{array}$ & 2,7193 & 1,09563 & \multirow{4}{*}{2,8769} \\
\hline & $\begin{array}{l}\text { 9. Bu kurum çalışanlarına iş rollerinde kullanmaları gereken malzeme ve ekipman desteği } \\
\text { vermektedir. }\end{array}$ & 3,0316 & 1,08009 & \\
\hline & $\begin{array}{l}\text { 10. Bu kurum çalışanları açısından sağlıklı bir iş ortam yapılandırmaya önem } \\
\text { vermektedir. }\end{array}$ & 2,8476 & 1,11156 & \\
\hline & $\begin{array}{l}\text { 11. } \mathrm{Bu} \text { kurumda çalışanların ihtiyaç duydukları kaynaklara ulaşmalarına firsat } \\
\text { verilmektedir. }\end{array}$ & 2,9089 & 1,05044 & \\
\hline \multirow{5}{*}{ 岂 } & 12. Bu kurumda çalışanların hizmetiçi eğitimlere katılmalarına önem verilmektedir. & 3,2305 & 1,04945 & \multirow{5}{*}{2,9416} \\
\hline & 13. Bu kurumda çalışanların çeşitli eğitim programlarına katılmaları desteklenmektedir. & 3,0706 & 1,07391 & \\
\hline & 14. Bu kurum çalışanların talep edildiğinde eğitim programları düzenlemektedir. & 2,9126 & ,99804 & \\
\hline & 15. Bu kurumda çalışanların mesleki gelişimlerine önem verilmektedir. & 2,6431 & 1,08784 & \\
\hline & 16. Bu kurumda ihtiyaç duyulması durumunda gereken eğitimler düzenlenmektedir. & 2,8513 & ,99543 & \\
\hline \multirow{5}{*}{ 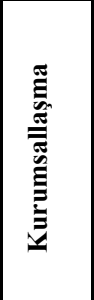 } & 18. Bu kurumun misyonu ve vizyonu belirgindir. & 3,3680 & 1,07202 & \multirow{5}{*}{3,1673} \\
\hline & 19. Bu kurum hizmet kalitesinin sağlanmasına önem vermektedir. & 3,1914 & 1,07907 & \\
\hline & 20. Bu kurumun tüm birimlerinde nitelikli personel istihdam edilmektedir. & 3,0669 & ,93114 & \\
\hline & 21. Bu kurum iş süreçlerinde etkinliğin sağlanmasına önem vermektedir. & 2,9665 & ,96821 & \\
\hline & 22. Bu kurumda tüm çalışanların açık görev tanımları vardır. & 3,2435 & ,97176 & \\
\hline \multirow{5}{*}{$\hat{\nexists}$} & 23. Bu kurum başarılı çalışanların ödüllendirilmesine önem vermektedir. & 2,0762 & ,99334 & \multirow{5}{*}{2,3535} \\
\hline & 24. Bu kurumda terfi politikaları etkili bir şekilde yürütülmektedir. & 2,2323 & 1,07793 & \\
\hline & 25. Bu kurumda politika ve prosedürler adaletli bir şekilde yürütülmektedir. & 2,4442 & 1,04892 & \\
\hline & 26. Bu kurumda iş süreçlerinde şeffaflığın sağlanmasına önem verilmektedir. & 2,5223 & 1,03947 & \\
\hline & 27. Bu kurumda çalışanlar için belirlenmiş açık performans kriterleri mevcuttur. & 2,4926 & 1,03610 & \\
\hline
\end{tabular}


Yapısal güçlendirme ölçeğinin değişken ortalamalarının; 2,23 ve 3,37 arasında sıralandığı, faktör ortalamalarının; 2,35 ve 3,17 arasında sıralandığı, değişkenlerin standart sapmalarının ise 0,93 ile 1,11 arasında sıralandığı görülmüştür. Bulgular personelin yapısal güçlendirme algısının orta düzeyde olduğunu göstermektedir.

Faktör analizi sonucunda örgütsel özdeşleşme ölçeğinin teoriye uygun bir yapıyı ölçtüğü ve yapı geçerliliğini sağladığı görülmüştür. Örgütsel özdeşleşme ölçeğinin faktör analizi sonuçları Tablo 5'de ve ölçeğin değişken ortalamaları, standart sapma, faktör ortalamaları Tablo 6'da gösterilmektedir.

Tablo 5. Örgütsel Özdeşleşme Ölçeği Döndürülmüş Faktör Yükleri

\begin{tabular}{|c|c|c|}
\hline Ölçek Maddeleri & Sadakat & $\begin{array}{c}\text { Benzerlik } \\
\text { Üyelik }\end{array}$ \\
\hline 3. Kurumumuzun başarısı için, benden beklenenin üzerinde bir çaba gösteriyorum. & 0,615 & \\
\hline 4. Dışarıdaki kişilerin çalıştığım kurumu eleştirmelerine sinirlenirim. & 0,779 & \\
\hline 5. Bu kuruma karşı samimi duygular besliyorum. & 0,869 & \\
\hline 9. Bu kurumdakiler aynı amaç doğrultusunda çalışıyorlar. & & 0,670 \\
\hline 10. Çalıştığım kurumun imajı toplum içerisinde beni iyi bir şekilde temsil etmektedir. & & 0,716 \\
\hline 16. Kendi değerlerimi, bu kurumun değerlerine oldukça yakın buluyorum. & & 0,741 \\
\hline 17. Bu kurumu, çalışanlarının çoğunun aidiyet hissi duyduğu büyük bir aile olarak tanımlıyorum. & & 0,805 \\
\hline 18. Kendimi bu kurum ile özdeşleştirmemin kolay olduğunu düşünüyorum. & & 0,812 \\
\hline 19. Para kazanmaya ihtiyacım olmasa bile bu kurumda çalışmaya devam edebilirim. & & 0,638 \\
\hline 20. Bu kurumun üyesi olmaktan gurur duyuyorum. & & 0,737 \\
\hline 22. Bu kurumun bana değer verdiğini düşünüyorum. & & 0,744 \\
\hline İç Tutarlılık Katsayıları (Cronbach's Alpha) & $\overline{6}, 645$ & $\overline{8}, 875$ \\
\hline Hesaplanan Genel İç Tutarlıık Katsayısı & \multicolumn{2}{|c|}{, 870} \\
\hline Açıklanan Varyanslar & 39,096 & 17,259 \\
\hline
\end{tabular}

Örgütsel özdeşleşme ölçek maddelerinin faktör analizine sokulması sonucunda iki faktörlü bir yapı elde edilmiştir. Oluşan faktörler toplam varyansın \% 56'sını açıklamaktadır. Birinci faktör sadakatin açıkladığı varyans oranı \% 39, ikinci faktör benzerlik-üyeliğin açıkladığı varyans oranı \% 17 olarak saptanmıştır. 
Tablo 6. Örgütsel Özdeşleşme Ölçeği Değişken Ortalamaları

\begin{tabular}{|c|c|c|c|c|}
\hline Faktör & Ölçek Maddeleri & $\begin{array}{l}\text { Değişken } \\
\text { Ortalama }\end{array}$ & $\begin{array}{l}\text { Standart } \\
\text { Sapma }\end{array}$ & $\begin{array}{l}\text { Faktör } \\
\text { Ortalama }\end{array}$ \\
\hline \multirow{3}{*}{ 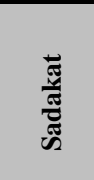 } & 3. Kurumumuzun başarısı için, benden beklenenin üzerinde bir çaba gösteriyorum. & 3,6543 & 1,03720 & \multirow{3}{*}{3,2677} \\
\hline & 4. Dışarıdaki kişilerin çalıştığım kurumu eleştirmelerine sinirlenirim & 2,9591 & 1,03307 & \\
\hline & 5. Bu kuruma karşı samimi duygular besliyorum. & 3,1896 & 1,04165 & \\
\hline \multirow{8}{*}{ 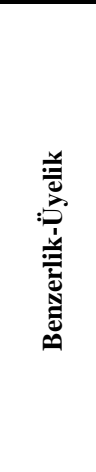 } & 9. Bu kurumdakiler aynı amaç doğrultusunda çalışıyorlar. & 3,0539 & 1,01885 & \multirow{8}{*}{2,7869} \\
\hline & 10. Çalıştı̆̆ım kurumun imajı toplum içerisinde beni iyi bir şekilde temsil etmektedir. & 3,0428 & ,97646 & \\
\hline & 16. Kendi değerlerimi, bu kurumun değerlerine oldukça yakın buluyorum. & 2,7993 & ,92786 & \\
\hline & $\begin{array}{l}\text { 17. Bu kurumu, çalışanlarının çoğunun aidiyet hissi duyduğu büyük bir aile olarak } \\
\text { tanımlıyorum. }\end{array}$ & 2,7565 & 1,04383 & \\
\hline & 18. Kendimi bu kurum ile özdeşleştirmemin kolay olduğunu düşünüyorum. & 2,8104 & ,98845 & \\
\hline & 19. Para kazanmaya ihtiyacım olmasa bile bu kurumda çalışmaya devam edebilirim. & 2,3327 & 1,15264 & \\
\hline & 20. Bu kurumun üyesi olmaktan gurur duyuyorum. & 2,9517 & ,96758 & \\
\hline & 22. Bu kurumun bana değer verdiğini düşünüyorum. & 2,5483 & 1,10462 & \\
\hline
\end{tabular}

Örgütsel özdeşleşme ölçeğinin değişken ortalamalarının; 2,33 ve 3,65 arasında sıralandığı, faktör ortalamalarının 2,79 ve 3,27 olduğu, standart sapmalarının ise 0,93 ve 1,15 arasında sıralandığ görülmüştür. Elde edilen bulgular personelin örgütsel özdeşleşme algısının orta düzeyde olduğunu göstermiştir.

Faktör analizi sonucunda yaşam doyumu ölçeğinin teoriye uygun bir yapıyı ölçtüğü ve yap1 geçerliliğini sağladığı görülmüştür. Yaşam doyumu ölçeğinin faktör analizi sonuçları Tablo 7'de ve ölçeğin değişken ortalamaları, standart sapma, faktör ortalaması Tablo 8'de gösterilmektedir.

Tablo 7. Yaşam Doyumu Ölçeği Döndürülmüş Faktör Yükleri

\begin{tabular}{|l|c|}
\hline \multicolumn{1}{|c|}{ Ölçek Maddeleri } & Yaşam Doyumu \\
\hline 1. Çoğu zaman yaşamımın hayalimdekine yakın olduğunu düşünüyorum. & 0,799 \\
\hline 2. Yasam koşullarımın mükemmel olduğunu düşünüyorum. & 0,826 \\
\hline 3. Genel olarak hayatımdan memnunum. & 0,708 \\
\hline 4. Şimdiye kadar hayatta istediğim önemli şeylere sahip olduğumu düşünüyorum. & 0,681 \\
\hline 5.Elimde yaşamımı değiştirebileceğim sihirli bir değnek olsa bile hiçbir şeyi değiştirmezdim. & 0,634 \\
\hline Hesaplanan Genel İç Tutarlılık Katsayısı &, $\mathbf{7 8 3}$ \\
\hline Açıklanan Varyans & $\mathbf{5 4 , 1 1 2}$ \\
\hline Çıkarım Yöntemi: Temel Bileşenler Analizi & \\
\hline
\end{tabular}

Yaşam doyumu ölçek maddelerinin faktör analizine sokulması sonucunda tek faktörlü bir yapı elde edilmiştir. Oluşan faktör toplam varyansın \% 54’ünü açıklamaktadır. 
Tablo 8. Yaşam Doyumu Ölçeği Değişken Ortalamaları

\begin{tabular}{|c|c|c|c|}
\hline Ölçek Maddeleri & $\begin{array}{l}\text { Değişken } \\
\text { Ortalama }\end{array}$ & $\begin{array}{l}\text { Standart } \\
\text { Sapma }\end{array}$ & $\begin{array}{c}\text { Faktör } \\
\text { Ortalama }\end{array}$ \\
\hline 1. Çoğu zaman yaşamımın hayalimdekine yakın olduğunu düşünüyorum. & 2,7230 & 1,08119 & \multirow{5}{*}{2,7896} \\
\hline 2. Yasam koşullarımın mükemmel olduğunu düşünüyorum. & 2,4665 & 1,06397 & \\
\hline 3. Genel olarak hayatımdan memnunum. & 3,2007 & 1,03416 & \\
\hline 4. Şimdiye kadar hayatta istediğim önemli şeylere sahip olduğumu düşünüyorum. & 3,2268 & ,97867 & \\
\hline $\begin{array}{l}\text { 5.Elimde yaşamımı değiştirebileceğim sihirli bir değnek olsa bile hiçbir şeyi } \\
\text { değiştirmezdim. }\end{array}$ & 2,3309 & 1,12124 & \\
\hline
\end{tabular}

Yaşam doyumu ölçeğinin değişken ortalamalarının 2,33 ve 3,22 arasında sıralandığ1; faktör ortalamasının 2,79 olduğu ve standart sapmaların 0,98 ve 1,12 olduğu görülmüştür. Elde edilen bulgular personelin yaşam doyumu algısının orta düzeyde olduğunu göstermiştir.

\section{Korelasyon analizine ilişkin bulgular}

Araştırma kapsamında değişkenler arasındaki ilişkileri test edebilmek amacıyla korelasyon analizi uygulanmıştır. Bu kapsamda yapısal güçlendirme, örgütsel özdeşleşme ve yaşam doyumu alt boyutları korelasyonları incelenmiştir. Korelasyon analizine ilişkin bulgular Tablo 9'da gösterilmiştir.

Tablo 9. Yapısal Güçlendirme, Örgütsel Özdeşleşme ve Yaşam Doyumu Alt Boyutlarına Yönelik Korelasyon Analizi Bulguları

\begin{tabular}{|c|c|c|c|c|c|c|c|c|c|}
\hline & & $\begin{array}{c}\text { Örgütsel } \\
\text { Destek }\end{array}$ & Kaynaklar & $\begin{array}{c}\text { Eğitim } \\
\text { Geliştrme }\end{array}$ & $\begin{array}{c}\text { Kurumsal- } \\
\text { laşma }\end{array}$ & $\dot{\mathrm{I} K \mathrm{KP}}$ & $\begin{array}{c}\text { Yaşam } \\
\text { Doyumu }\end{array}$ & Sadakat & $\begin{array}{l}\text { Benzerlik- } \\
\text { Üyelik }\end{array}$ \\
\hline Örgütsel & PearsonCorrelation & 1 & & & & & & & \\
\hline Destek & Sig. (2-tailed) & 000 & & & & & & & \\
\hline \multirow{2}{*}{ Kaynaklar } & PearsonCorrelation & $509 * *$ & 1 & & & & & & \\
\hline & Sig. (2-tailed) & 000 & & & & & & & \\
\hline \multirow{2}{*}{$\begin{array}{c}\text { Eğitim } \\
\text { Geliştirme }\end{array}$} & PearsonCorrelation & $660 * *$ & $592 * *$ & 1 & & & & & \\
\hline & Sig. (2-tailed) & 000 & 000 & & & & & & \\
\hline \multirow{2}{*}{ Kurumsallaşma } & PearsonCorrelation & $512 * *$ & $516 * *$ & $533 * *$ & 1 & & & & \\
\hline & Sig. (2-tailed) & 000 & 000 & 000 & & & & & \\
\hline \multirow{2}{*}{ İKP } & PearsonCorrelation & $566 * *$ & $568 * *$ & $597 * *$ & $491 * *$ & 1 & & & \\
\hline & Sig. (2-tailed) & 000 & 000 & 000 & 000 & & & & \\
\hline \multirow{2}{*}{$\begin{array}{c}\text { Yaşam } \\
\text { Doyumu }\end{array}$} & PearsonCorrelation & $400 * *$ & $303 * *$ & $425 * *$ & $275 * *$ & $357 * *$ & 1 & & \\
\hline & Sig. (2-tailed) & 000 & 000 & 000 & 000 & 000 & & & \\
\hline \multirow{2}{*}{ Sadakat } & PearsonCorrelation & $420 * *$ & $393 * *$ & $500 * *$ & $388 * *$ & $338 * *$ & $239 * *$ & 1 & \\
\hline & Sig. (2-tailed) & 000 & 000 & 000 & 000 & 000 & 000 & & \\
\hline \multirow{2}{*}{$\begin{array}{c}\text { Benzerlik- } \\
\text { Üyelik }\end{array}$} & PearsonCorrelation & $590 * *$ & $521 * *$ & $656^{* * *}$ & $519 * *$ & $676 * *$ & $485 * *$ & $498 * *$ & 1 \\
\hline & Sig. (2-tailed) & 000 & 000 & 000 & 000 & 000 & 000 & 000 & \\
\hline 1 & & & & & & & & & \\
\hline
\end{tabular}


Tablo 9'da araştırma kapsamında incelenen yapısal güçlendirme (örgütsel destek, kaynaklar, eğitim ve geliştirme, kurumsallaşma, insan kaynakları politikaları), örgütsel özdeşleşme (sadakat, benzerliküyelik) ve yaşam doyumu değişkenlerinin boyutları arasındaki korelasyon değerleri görülmektedir. Araştırma sonuçları yapısal güçlendirme boyutları ile örgütsel özdeşleşme boyutları ve yaşam doyumu arasında pozitif yönlü ve anlamlı ilişkiler olduğunu göstermiş̧tir $(\mathrm{p}<0,01)$.

\section{Ölçüm modeline ilişkin bulgular}

Ölçüm modeli kapsamında ayrışım ve benzeşim geçerlilikleri test edilmiştir. Benzeşim geçerliliği kapsamında faktör yükleri, birleşik güvenilirlik (CR) değerleri ve ortalama açıklanan varyans (AVE) değerleri hesaplanmıştır. Tablo 10 'da görüldüğü gibi faktör yükleri 0,6 'dan, birleşik güvenilirlik değerleri 0,7 'den, ortalama açıklanan varyans değerleri ise 0,5 'ten yüksek olduğundan, analiz sonuçları kabul edilebilir değer aralığındadır (Uppal vd., 2018).

Tablo 10. Geçerlilik ve Güvenilirlik Analizleri

\begin{tabular}{|l|c|c|c|c|}
\hline Değişkenler & Faktör Yükleri & Cronbach's Alpha & CR & AVE \\
\hline Örgütsel Destek & $0,636-0,886$ & 0,888 & 0,915 & 0,645 \\
\hline Kaynaklar & $0,785-0,851$ & 0,837 & 0,891 & 0,671 \\
\hline Eğitim ve Geliştirme & $0,711-0,852$ & 0,840 & 0,887 & 0,612 \\
\hline Kurumsallaşma & $0,716-0,842$ & 0,860 & 0,899 & 0,642 \\
\hline İnsan Kaynakları Politikaları & $0,758-0,868$ & 0,882 & 0,914 & 0,680 \\
\hline Yaşam Doyumu & $0,634-0,826$ & 0,785 & 0,852 & 0,538 \\
\hline Sadakat & $0,615-0,869$ & 0,645 & 0,803 & 0,580 \\
\hline Benzerlik ve Üyelik & $0,638-0,812$ & 0,877 & 0,903 & 0,540 \\
\hline
\end{tabular}

Çalışmada bir sonraki adım olarak ayrışım geçerliliği sonuçları değerlendirilmiştir. Ayrışım geçerliliği; her yapının ortalama açıklanan varyansının karekökünün, o yapıların korelasyon katsayılarından daha büyük olması gerektiğini savunmaktadır (Fornell ve Larcker, 1981).

Ayrışım geçerliliğine ilişkin bulgular Tablo 11'de gösterilmiştir. Görüldügüü üzere her bir yapı, ilişkili olduğu yapının korelasyon katsayısından daha yüksek değerlere sahiptir. Buna göre ölçüm modelinin benzeşim geçerliliği ve ayrışım geçerliliği kriterlerini sağladığını söylemek mümkündür. 
Tablo 5.11. Ayrışım Geçerliliğine İlişkin Bulgular

\begin{tabular}{|c|c|c|c|c|c|c|c|c|}
\hline Değişkenler & $\begin{array}{l}\text { Örgütsel } \\
\text { Destek }\end{array}$ & Kaynaklar & \begin{tabular}{|c|} 
Eğitim \\
Geliştirme
\end{tabular} & $\begin{array}{l}\text { Kurum- } \\
\text { sallaşma }\end{array}$ & $\begin{array}{ll}\text { İnsan Kay. } \\
\text { Pol. }\end{array}$ & $\begin{array}{l}\text { Yaşam } \\
\text { Doyumu }\end{array}$ & Sadakat & $\begin{array}{l}\text { Benzerlik- } \\
\text { Üyelik }\end{array}$ \\
\hline Örgütsel Destek & $\mathbf{0 , 8 0 3}$ & & & & & & & \\
\hline Kaynaklar & 0,519 & 0,819 & & & & & & \\
\hline Eğitim Geliştirme & 0,661 & 0,601 & $\mathbf{0 , 7 8 3}$ & & & & & \\
\hline Kurumsallaşma & 0,519 & 0,520 & 0,532 & $\mathbf{0 , 8 0 1}$ & & & & \\
\hline İnsan Kay. Pol. & 0,581 & 0,575 & 0,603 & 0,498 & 0,824 & & & \\
\hline Yașam Doyumu & 0,410 & 0,311 & 0,428 & 0,277 & 0,371 & $\mathbf{0 , 7 3 3}$ & & \\
\hline Sadakat & 0,441 & 0,414 & 0,528 & 0,400 & 0,376 & 0,276 & 0,762 & \\
\hline Benzerlik-Üyelik & 0,597 & 0,524 & 0,657 & 0,526 & 0,681 & 0,487 & 0,537 & $\mathbf{0 , 7 3 5}$ \\
\hline
\end{tabular}

\section{Yapısal modele ilişkin bulgular}

Çalışma kapsamında Smart PLS v3 programı kullanılarak kısmi en küçük kareler yöntemiyle modelleme yapılmış ve hipotezler test edilmiştir. Bu adımda, açıklama gücü için standart $\mathrm{R}^{2}$ ve modele uygunluğun değerlendirilmesi için standart kök ortalama kare kalıntısı (SRMR) hesaplanmıştır.

Şekil 1'de görülen modelde SRMR değerin önerilen 0,08 değerinin altında olan 0,067 değerini almıştır. Bu da modelin kabul edilebilir sınırlar içinde olduğunu göstermektedir. Standardize edilmiş $\mathrm{R}^{2}$ değeri; bağımsız değişkenin bağımlı değişken üzerindeki açıklayıcılık seviyesini ifade etmektedir. Buna göre bağımsız değişken olan yapısal güçlendirmenin bağımlı değişkenlerden yaşam doyumunu açıklama oranı (\% 22) iken, bir diğer bağımlı değişken olan örgütsel özdeşleşmenin sadakat boyutunu (\% 31), benzerlik-üyelik boyutunu ise (\% 58) düzeyinde açıkladığı görülmüştür. Bu sonuçlara göre; yapısal güçlendirme uygulamalarının kamu kurumlarında örgütlerine aidiyet düzeyleri üzerinde daha belirgin bir etki oluşturduğu ifade edilebilir. Kamu kurumlarında yapısal güçlendirme uygulamaları personelin kendi değerleri ile örgütün değerlerini daha fazla benzer görmelerine ve kendini örgütün bir üyesi olarak tanımlamalarına katkı sağlamaktadır. 


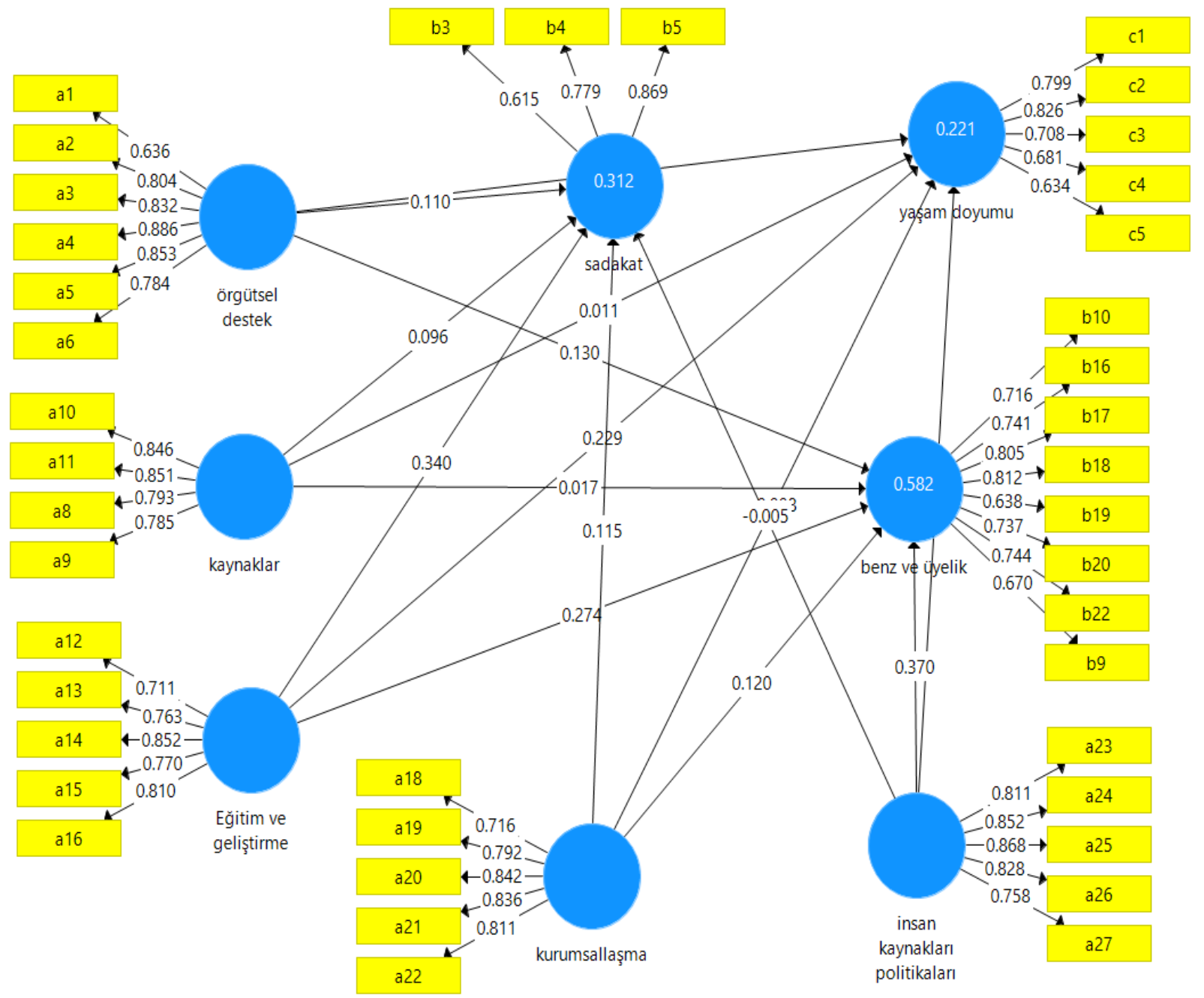

Şekil 1'de yapısal model verilmiş olup, Tablo 12'de ise yapısal model ve hipotez testlerinin etkileri belirtilmiştir.

Tablo 12. Yapısal Modelin Etkileri ve Hipotez Testleri

\begin{tabular}{|c|c|c|c|c|c|c|c|}
\hline \multicolumn{4}{|c|}{ Hipotezler } & $\boldsymbol{\beta}$ & t değeri & p değeri & Sonuçlar \\
\hline $\mathrm{H}_{1 \mathrm{a}}$ & Örgütsel Destek & & Sadakat & 0,110 & 2,141 & 0,032 & Doğrulandı \\
\hline $\mathrm{H}_{1 \mathrm{~b}}$ & Örgütsel Destek & & Benzerlk-Üyelik & 0,130 & 3,292 & 0,001 & Doğrulandı \\
\hline$\overline{\mathrm{H}_{2 \mathrm{a}}}$ & Örgütsel Destek & & Yaşam Doyumu & 0,186 & 3,317 & 0,001 & Doğrulandı \\
\hline$\overline{\mathrm{H}_{1 \mathrm{c}}}$ & Kaynaklar & & Sadakat & 0,096 & 1,847 & 0,065 & Doğrulanmadı* \\
\hline $\mathrm{H}_{1 \mathrm{~d}}$ & Kaynaklar & & Benzerlk-Üyelik & 0,017 & 0,402 & 0,688 & Doğrulanmadı* \\
\hline $\mathrm{H}_{2 \mathrm{~b}}$ & Kaynaklar & & Yaşam Doyumu & 0,011 & 0,189 & 0,850 & Doğrulanmadi* \\
\hline$\overline{\mathrm{H}_{\mathrm{ee}}}$ & Eğitm-Geliştirme & & Sadakat & 0,340 & 5,817 & 0,000 & Doğrulandı \\
\hline $\mathrm{H}_{1 \mathrm{f}}$ & Eğitm-Geliştirme & & Benzerlk-Üyelik & 0,274 & 6,069 & 0,000 & Doğrulandı \\
\hline$\overline{\mathrm{H}_{2 \mathrm{c}}}$ & Eğitm-Geliştirme & & Yaşam Doyumu & 0,229 & 3,701 & 0,000 & Doğrulandı \\
\hline $\mathrm{H}_{1 \mathrm{~g}}$ & Kurumsallaşma & & Sadakat & 0,115 & 2,308 & 0,021 & Doğrulandı \\
\hline
\end{tabular}




\begin{tabular}{|c|c|c|c|c|c|c|}
\hline$\overline{\mathrm{H}_{1 \mathrm{~h}}}$ & Kurumsallaşma & Benzerlk-Üyelik & 0,120 & 3,032 & 0,002 & Doğrulandı \\
\hline $\mathrm{H}_{2 \mathrm{~d}}$ & Kurumsallaşma & Yaşam Doyumu & $-0,008$ & 0,148 & 0,882 & Doğrulanmadi* ${ }^{*}$ \\
\hline $\mathrm{H}_{1 \mathrm{i}}$ & $\dot{\mathrm{I} K P}$ & Sadakat & $-0,005$ & 0,095 & 0,924 & Doğrulanmadi* \\
\hline $\mathrm{H}_{1 \mathrm{j}}$ & $\dot{\mathrm{I} K P}$ & BenzerlkÜyelik & 0,370 & 8,545 & 0,000 & Doğrulandı \\
\hline $\mathrm{H}_{2 \mathrm{e}}$ & $\overline{\mathrm{IIKP}}$ & Yaşam Doyumu & 0,123 & 2,028 & 0,043 & Doğrulandı \\
\hline
\end{tabular}

Tablo 12'ye göre;

- Yapısal güçlendirmenin örgütsel destek boyutu, örgütsel özdeşleşmenin sadakat $(\beta=0,110 ; \mathrm{t}$ değeri=2,141) ve benzerlik-üyelik boyutunu $(\beta=0,130 ; \mathrm{t}$ değeri=3,292) pozitif ve anlamlı olarak etkilemektedir. Örgütsel destek aynı zamanda yaşam doyumunu da pozitif ve anlamlı olarak etkilemektedir $\left(\beta=0,186\right.$; $\mathrm{t}$ değeri=3,317). Dolayısıyla $\mathrm{H}_{1 \mathrm{a}}, \mathrm{H}_{1 \mathrm{~b}}$ ve $\mathrm{H}_{2 \mathrm{a}}$ hipotezleri doğrulanmıştır.

- Yapısal güçlendirmenin kaynaklar boyutunun sadakat, benzerlik-üyelik ve yaşam doyumu değişkenleri üzerinde herhangi bir etkisi bulunmadığı görülmüştür. $H_{1 c}, H_{1 d}$ ve $H_{2 b}$ hipotezleri doğrulanmamıştır.

- Eğitim ve geliştirme boyutu, yaşam doyumunu pozitif ve anlamlı olarak etkilerken $(\beta=0,229$; $\mathrm{t}$ değeri=3,701); sadakat $(\beta=0,340 ; \mathrm{t}$ değeri=5,817) ve benzerlik-üyelik $(\beta=0,274 ; \mathrm{t}$ değeri=6,069) boyutlarını da pozitif ve anlamlı olarak etkilemektedir. Bu bulgular 1şığında $\mathrm{H}_{1 \mathrm{e}}, \mathrm{H}_{1 \mathrm{f}}$ ve $\mathrm{H}_{2 \mathrm{c}}$ hipotezleri doğrulanmıştır.

- Kurumsallaşma boyutunun sadakat $(\beta=0,115$; $\mathrm{t}$ değeri=2,308) ve benzerlik-üyelik $(\beta=0,120$; değeri=3,032) boyutlarını ise pozitif ve anlamlı olarak etkilediği görülmüş ve $\mathrm{H}_{1 \mathrm{~g}}$ ve $\mathrm{H}_{1 \mathrm{~h}}$ hipotezleri doğrulanmıştır. Kurumsallaşma boyutunun yaşam doyumu üzerinde bir etkisi olmadığı tespit edilmiş ve $\mathrm{H}_{2 \mathrm{~d}}$ hipotezi doğrulanmamıştır.

- İnsan kaynakları politikalarının benzerlik-üyelik boyutunu $(\beta=0,370 ; \mathrm{t}$ değeri=8,545) pozitif ve anlamlı olarak etkilediği görülmüş ve $\mathrm{H}_{1 \mathrm{i}}$ hipotezi doğrulanmıştır. Ancak, insan kaynakları politikalarının sadakat üzerinde herhangi bir etkisi olmadığı sonucuna ulaşılmış ve $H_{1 j}$ hipotezi doğrulanmamıştır. Son olarak insan kaynakları politikalarının yaşam doyumunu pozitif ve anlamlı olarak etkilediği görülmüş $\left(\beta=0,123\right.$; $\mathrm{t}$ değeri=2,028) ve $\mathrm{H}_{2 \mathrm{e}}$ hipotezi doğrulanmıştır.

\section{Bulguların Tartışılması}

Gerçekleştirilen korelasyon analizi sonucunda, yapısal güçlendirme ile örgütsel özdeşleşme arasında oldukça güçlü bir ilişki olduğu saptanmıştır. En güçlü ilişkinin yapısal güçlendirmenin insan kaynakları politikaları boyutuyla, örgütsel özdeşleşmenin benzerlik-üyelik boyutu arasında olduğu görülmüştür. Özellikle kurumların uyguladığı personele değer veren insan kaynakları politikalarının, 
örgüte aidiyet duygusunun artmasına katkı sağlayacağını ifade etmek mümkündür. Bununla birlikte yapısal güçlendirmenin boyutları ile yaşam doyumu arasında da güçlü ilişkiler olduğu görülmüştür. En güçlü ilişkinin ise yapısal güçlendirmenin eğitim ve geliştirme boyutu ile yaşam doyumu arasında olduğu tespit edilmiştir. Bu sonuç, personelin kişisel gelişimlerine destek olan fursatlar sağlanması ile onların genel yaşamlarını olumlu algılama ve mutluluk duyguları arasında güçlü ilişkiler olduğunu göstermektedir.

Korelasyon analizi sonucunda belirlenen ilişkilerin niteliği regresyon analizi ile açıklanmıştır. Araştırma modelindeki bağımsız değişkenlerin, bağımlı değişkenleri etkileme düzeyleri ile bağımsız ve bağımlı değişkenlerin kendi aralarındaki etkileşim düzeylerinin belirlenmesi amacıyla gerçekleştirilen regresyon analizi sonucunda elde edilen bulgular şu şekilde değerlendirilmiştir:

- Bağımsız değişken olan yapısal güçlendirmenin bağımlı değişkenlerden yaşam doyumunu açıklama oranı \% 22, bir diğer bağımlı değişken olan örgütsel özdeşleşmenin sadakat boyutunu \% 31 ve benzerlik-üyelik boyutunu \% 58 oranında açıkladığı görülmüştür.

Yapısal güçlendirmenin örgütsel özdeşleşmeyi açıklama oranının önemli düzeyde olduğu saptanmıştır. $\mathrm{Bu}$ sonuç yapısal güçlendirme uygulamalarının personelin kendi değerleri ile örgütün değerlerini benzer görmelerine, kimliklerini örgütüyle tanımlamalarına aynı zamanda örgütüyle gurur duyarak kendini örgüte ait olarak algılamalarını önemli düzeyde etkilediğini ifade etmektedir. Araştırma bulguları yapısal güçlendirmenin yordadığı örgütsel özdeşleşme ile örgütsel olumlu çıktılar elde edilebileceğini göstermektedir. Kurumlarda yapısal güçlendirme uygulamaları büyük oranda benzerlik-üyelik duygusunu açıklamaktadır. Dolayısıyla kamu kurumlarında yapısal güçlendirme uygulamaları örgüt yönetimlerine hem personel üzerinde hem de örgütsel olarak olumlu sonuçlar elde edebilmelerinde avantaj sağlamaktadır.

- Yapısal güçlendirmenin örgütsel destek boyutunun, örgütsel özdeşleşmenin sadakat ve benzerliküyelik boyutunu pozitif ve anlamlı olarak etkilediği saptanmıştır. Elde edilen sonucun alanyazındaki çalışmalarla benzerlik gösterdiği (Kerse ve Karabey, 2017; Battal ve Soyalın, 2020) görülmüştür. Kamu kurumlarında çalışanların yeni fikirler geliştirmelerinin, bilgi ve becerilerini kullanmalarının desteklenmesi durumunda ve yöneticilerin liderlik rolleri üstlenmeleri ile çözüm odaklı bakış açısıyla yaklaşmaları, personelin örgüte sadakat duygusunu etkilemekte aynı zamanda örgütün değerleriyle kendi değerlerini benzer görmelerine ve üyelik duygusu geliştirmelerine katkı sağlayabilmektedir.

- Yapısal güçlendirmenin kaynaklar boyutunun örgütsel özdeşleşmenin sadakat ve benzerlik-üyelik değişkenleri üzerinde herhangi bir etkisi bulunmadığı saptanmıştır. Yapılan çalışmalar incelendiğinde yapısal güçlendirme uygulamaları ile personele sağlanan donanım, malzeme gibi kaynakların onların 
özdeşleşme algılarını etkileyeceği beklenmektedir (Erbay ve Turgut, 2015; Özarallı, 2017). Elde edilen bu sonuç alanyazındaki çalışmalarla farklılık göstermektedir. Kamu kurumlarında işleri başarmada yeterli düzeyde personel, teknolojik araç-gereç, malzeme ve ekipman sağlanmasının personelin sadakat ve benzerlik-üyelik duygusunun gelişmesinde etkisi olmadığı sonucuna ulaşılmıştır. Bu sonuç, kamu kurumlarında personele sağlanan kaynaklardan ziyade insan kaynakları politikalarına ilişkin hususların daha önemli olduğunu göstermektedir.

- Yapısal güçlendirmenin eğitim ve geliştirme boyutunun örgütsel özdeşleşmenin sadakat ve benzerlik-üyelik boyutlarını pozitif ve anlamlı olarak etkilediği saptanmıştır. Alanyazın incelendiğinde personele sağlanan eğitim ve geliştirme fırsatları onların özdeşleşme düzeylerini etkileyebileceği (Özarallı, 2017; Erkul vd., 2018) ve elde edilen bulguların alanyazındaki çalışmaları desteklediği görülmüştür. Kamu kurumlarında personelin mesleki gelişimlerine önem verilmesi, hizmetiçi eğitimler verilmesi, ihtiyaç halinde ve talep edildiğinde eğitim programlarına katılmalarının sağlanması onların örgütlerine karşı sadakat duygusunu geliştirmekte, kendilerini örgütün bir üyesi olarak algılamalarını ve örgütle özdeşleşmelerini sağlamaktadır.

- Yapısal güçlendirmenin kurumsallaşma boyutunun örgütsel özdeşleşmenin sadakat ve benzerliküyelik boyutlarını pozitif ve anlamlı olarak etkilediği saptanmıştır. Alanyazında örgütlerin kurumsallaşma düzeylerinin örgütsel özdeşleşmeyi olumlu yönde etkileyeceği (Mael ve Ashforth, 1992; Özgözgü, 2016) saptanmış ve elde edilen bulgular bu sonuçları desteklemiştir. Örgütlerin iş süreçlerinde etkinliği ve yüksek hizmet kalitesi sağlamaya, nitelikli personel istihdam etmeye önem vermesi ayrıca görev tanımlarının, misyon ve vizyon tanımlarının belirgin olması ve aynı zamanda örgütün toplumun gözünde olumlu bir imaja sahip olması, personelin sadakat duygusunun gelişmesine ve kendilerini örgütleriyle aynı kimlikte algılamasına böylece özdeşleşme düzeylerinin artmasına katkı sağlamaktadır.

- Yapısal güçlendirmenin insan kaynakları politikaları boyutu örgütsel özdeşleşmenin benzerliküyelik boyutunu pozitif ve anlamlı olarak etkilemekte ancak, sadakat boyutu üzerinde herhangi bir etkisi olmadığı sonucuna ulaşılmıştır. Yapılan önceki çalışmalar (Tüzün ve Çağlar, 2008; Chen vd., 2015) örgütlerin insan kaynakları politikalarının örgütsel özdeşleşmeyi etkilediğini göstermektedir. İnsan kaynakları politikalarının personelin benzerlik-üyelik algısı üzerindeki etkileri alanyazındaki bulguları destekler iken sadakat düzeyleri üzerindeki etkileri diğer çalışmalardan farklılık göstermiştir. Kamu kurumlarında uygulanan ödüllendirme, açık performans kriterleri, terfi ve teşvik politikalarının varlığı, aynı zamanda iş süreçlerinin şeffaf, politika ve prosedürlerin adaletli bir şekilde yürütülmesi personelin örgütleriyle benzerlik algılarını ve üyelik duygularını geliştirerek özdeşleşmelerini etkilemektedir. Ancak personelin sadakat duygularının gelişiminde insan kaynakları politikalarının 
anlamlı bir etkisi bulunmamaktadır. Bu sonuç ile uygulanan insan kaynakları politikalarının personel tarafından olumlu olarak algılanmadı ̆̆ 1 ifade edilebilir.

- Yapısal güçlendirmenin örgütsel destek, eğitim ve geliştirme firsatları ile insan kaynakları politikaları boyutlarının personelin yaşam doyumu algılarını pozitif ve anlamlı olarak etkilediği saptanmıştır. Ancak yapısal güçlendirenin kurumsallaşma ve kaynaklar boyutlarının personelin yaşam doyumu algıları üzerinde herhangi bir etkisi bulunmadığı görülmüştür. Alanyazında yapısal güçlendirme uygulamalarının personelin yaşam doyumu algısını olumlu etkileyeceğine yönelik çalışmalar saptanmıştır (De Almeida ve Orgambidez, 2019; Foy vd., 2019; Bernarto vd., 2020). Elde edilen sonuçlara göre personele sağlanan eğitim ve geliştirme firsatları, örgütsel destek ve uygulanan insan kaynakları politikalarının bu bulguları desteklediği görülmüştür. Personele sağlanan örgütsel destek onların iş süreçlerinde karşılaştıkları problemler karşısında yardım alacakları duygusu yaratarak daha az olumsuz duygular yaşamalarına neden olabilmektedir. Ayrıca eğitim ve gelişim firsatları onların öz yeterlilik ve özgüven düzeylerinin gelişmesine katkı sağlayabilmektedir. Bununla birlikte uygulanan insan kaynakları politikalarının onların motivasyonlarını artırarak daha fazla olumlu duygular yaşamalarına yol açabilmektedir. Böylece iş yaşamından aldıkları doyum, genel yaşamına yayılmakta ve yaşam doyumlarını artırabilmektedir. Yapısal güçlendirme uygulamaları ile personele iş süreçlerinde sağlanan kaynaklar ve örgütün kurumsallaşma düzeyinin ise personelin genel yaşam doyumu algısı üzerinde doğrudan bir etkisi olmadığı görülmektedir.

Elde edilen bulgulara göre; genel olarak yapısal güçlendirme uygulamalarının örgütsel özdeşleşme ve yaşam doyumu üzerinde etkisi olduğunu ifade etmek mümkündür. Kurumların personele sağladıkları örgütsel destek düzeyi arttığında; personelin örgütsel özdeşleşme ve yaşam doyumu düzeylerinin arttığı görülmektedir. Benzer şekilde kurumların eğitim ve geliştirme firsatı sağlama düzeyleri arttı̆̆ında, personelin örgütsel özdeşleşme ve yaşam doyumu düzeyleri de artış göstermektedir. Kurumlar tarafından sağlanan maddi kaynakların ise personelin örgütsel özdeşleşme ve yaşam doyumu düzeyleri üzerinde herhangi bir etkisinin bulunmadığı görülmektedir. Kurumların kurumsallaşma düzeyi arttıkça personelin örgütsel özdeşleşme düzeyi de artarken, yaşam doyumu düzeyinde herhangi bir etki görülmemektedir. Kurumların insan kaynakları politikaları ise personelin yaşam doyumu düzeyi ile sadakat düzeyi artırırken, benzerlik ve üyelik düzeylerini etkilememektedir.

Post-modern bir yönetim tekniği olarak yapısal güçlendirmenin, kamu kurumlarında örgütsel ve bireysel olarak olumlu çıktılara yol açtı̆̆ı araştırma sonucunda kanıtlanmıştır. Yapısal güçlendirme uygulamaları, personelin örgütsel özdeşleşme ve yaşam doyumu algılarını artırmaktadır. Dolayısıyla kendi değerleriyle örgütsel değerleri bir gören, bağlılık duygusu gelişen personel çalışma yaşamında 
daha etkin ve verimli rol almaktadır. Bununla birlikte yapısal güçlendirme personelin genel yaşamını daha anlamlı bularak mutlu ve üretken olabilmelerini sağlamaktadır. Sonuç olarak; kamu yöneticilerinin yapısal güçlendirme uygulamalarına daha fazla önem vermeleri olumlu örgütsel ve bireysel çıktılar elde etmelerinde katkı sağlayabilmektedir.

\section{SONUÇ VE ÖNERILER}

Yapısal güçlendirme giderek önem kazanan post-modern bir yönetim tekniği olarak kabul edilmektedir. Yapısal güçlendirmenin ana felsefesi kurumsal başarının personele başarma firsatı sağlayan bir yapıdan geçtiği üzerine kurulmuştur. Bu kapsamda çalışanların işlerinde ihtiyaç duydukları bilgiye, kaynağa, desteğe erişimlerine ve onların gelişimlerine firsat sağlayan bir ortam oluşturmak, kurumsal başarı elde etmede kritik önem arz etmektedir. Temelleri özel sektöre dayanan yapısal güçlendirmenin, 1980 sonrası Yeni Kamu Yönetimi anlayışıla birlikte kamu yönetiminde de kullanıldı̆̆ görülmüştür.

Yapılan alan araştırması ile şu sonuca ulaşılmıştır: "Kamu kurumlarında yapısal güçlendirme uygulamaları personelin örgütsel özdeşleşme ve yaşam doyumu algılarını olumlu yönde etkilemektedir". Alanyazından yola çıkarak geliştirilen model çerçevesinde, araştırma hipotezleri doğrulanmış ve değişkenler arasındaki ilişkiler test edilmiştir. Bununla birlikte bağımsız değişken yapısal güçlendirmenin (kaynaklar boyutu dişında, örgütsel destek, eğitim ve geliştirme, kurumsallaşma, insan kaynakları politikaları), bağımlı değişkenler örgütsel özdeşleşme (sadakat, benzerlik-üyelik) ve yaşam doyumu değişkenlerini etkilediği görülmüştür. Bu bağlamda, gerçekleştirilen analizler ve elde edilen bulgular araştırma modelindeki ilişkileri istatistiksel olarak açıklamakta ve ölçeklerin mevcut haliyle benzer araştırmalarda kullanılabileceğini ortaya koymaktadır.

Post-modern bir yönetim tekniği olarak kullanılan ve kamu yönetiminde kendi özellikleri çerçevesinde uygulandığı tespit edilen yapısal güçlendirmenin, yapılan alan araştırması ile kamu kurumlarında örgütsel ve bireysel olarak olumlu çıktılara yol açtığı kanıtlanmıştır. Yapısal güçlendirme uygulamaları, örgütleri ile özdeşleşmiş ve yaşam doyumu algıları yüksek çalışanların hem çalışma yaşamında daha etkin ve verimli rol almakta hem de genel yaşamını daha anlamlı bularak mutlu ve üretken olabilmektedirler. Dolayısıyla kamu yöneticilerinin yapısal güçlendirme uygulamalarına daha fazla önem vermeleri olumlu örgütsel ve bireysel çıktılar elde etmeye katkı sağlayabilecektir.

Araştırmanın yapısal güçlendirmenin (örgütsel destek, kaynaklar, eğitim ve geliştirme, kurumsallaşma, insan kaynakları politikaları), örgütsel özdeşleşme (sadakat ve benzerlik-üyelik) ve yaşam doyumu arasındaki ilişkileri bir yapısal model çerçevesinde açıklaması sebebiyle ilgili alana bir 
katkı sağladığı düşünülmektedir. Ancak araştırmanın sonuçları araştırma kapsamındaki kamu kurumları için geçerlidir. Dolayısıyla farklı kamu kurumlarında farklı sonuçlara ulaşılabileceği varsayılmakta ve modelin genellenebilir olması için farklı kamu kurumlarında da test edilmesi gerekmektedir.

Araştırma sonucuna göre kamu yöneticilerine şunlar önerilmektedir.

- Covid-19 pandemisi gibi kriz dönemlerinde nitelikli insan kaynakları ön plana çıkmış ve krizin aşılmasında kritik önem arz etmiştir. İşine bağlı ve örgütüyle özdeşleşmiş çalışanlar kriz ile mücadelede fark yaratmıştır. Bu sadece sağlık alanında değil kamu yönetiminin her alanında fark yaratacaktır. Dolayısıyla kamu yöneticilerine insan kaynakları politikalarına daha fazla önem vermeleri önerilir.

- Bugün olduğu kadar gelecek içinde insan kaynaklarının kapasitesinin ve niteliklerinin artırılması bir gerekliliktir. Eğitim ve geliştirme fırsatları yaratarak, katılımı ve yenilikçi davranışı teşvik ederek, bilgi çağında bilginin paylaşımı ve kullanımını sağlayarak sürekli bir ilerleme sağlanmalıdır. Bununla birlikte personelin teknoloji kullanımı da geliştirilmelidir. Kamu yöneticileri, araştırma sonuçlarının da desteklediği; eğitim ve geliştirme firsatları sunmaya ve desteklemeye daha fazla önem vermeli, post-modern yönetim tekniklerine yönelmelidir. Bu noktada yapısal güçlendirme uygulamaları öne çıkmaktadır.

- Yapılan alan araştırmasında yönetim tarzının yapısal güçlendirme uygulamalarında önemli olduğu görülmüştür. Yapısal güçlendirme uygulamalarına yönelecek yöneticilerin katılımcı, demokratik ve yenilikçi yönetim tarzları benimsemeleri uygulamanın başarılı olmasını etkileyecektir. Aynı zamanda elde edilen bulgular göstermektedir ki artık kamu yönetimlerinden sosyal sorumluluk projelerine daha fazla önem vermeleri, kurumsal imajı yükselten çabalar göstermeleri beklenmektedir. Yapısal güçlendirmenin başarılı bir şekilde uygulanmasında, kamu yöneticilerinin yönetim tarzlarında daha fazla katılımcı, yenilikçi ve demokratik olmaları ayrıca kurumsal itibarı yükseltecek sosyal sorumluluk projelerine önem vermeleri önerilmektedir.

- Yapısal güçlendirme kamu örgütlerinde post-modern bir yönetim tekniği olarak uygulandığında güçlendirilmiş yapı ve personel ile etkili hizmet sunumunun sağlanmasına, kaynakların daha etkili kullanımına ve hatta maliyetlerin azaltılmasına, rekabet edebilme potansiyelinin geliştirilmesine neden olabilmektedir. Dolayısıyla yapısal güçlendirme yönetsel, mali, hizmet ve personel ile ilgili sorunlar yaşayan kamu kurumlarına bir çözüm alternatifi olarak önerilmektedir.

Post-modern yönetim anlayışının uygulanmasında önemli bir teknik olan yapısal güçlendirme, başta personelin örgütsel özdeşleşmesinin ve yaşam doyumunun sağlanmasında önemli bir araçtır. Aynı 
zamanda kamu kurumlarına yönelik geliştirilen yapısal güçlendirme ölçeği boyutlarıyla Yeni Kamu Yönetimi anlayışını destekler niteliktedir. 


\section{KAYNAKÇA}

Akçakaya, Murat (2010). Örgütlerde Uygulanan Personel Güçlendirme Yöntemleri: Türk Kamu Yönetiminde Personel Güçlendirme. Karadeniz Araştırmaları, 25 (1), 145174.

Alkan, Durmuş Ali (2010). Türk Kamu Yönetiminde Personel Güçlendirme Kavramı ve Bir İnceleme. Yayımlanmamış Yüksek Lisans Tezi, Dumlupınar Üniversitesi Sosyal Bilimler Enstitüsü, Kütahya.

Almost, Joan, and Heather K. Spence Laschinger (2002). Workplace Empowerment, Collaborative Work Relationships, and Job Strain in Nurse Practitioners. Journal of the American Academy of Nurse Practitioners, 14 (9), 408-420.

Ashforth, Blake E.; Harrison, Spencer H.; Corley, Kevin G. (2008). Identification in Organizations: An Examination of Four Fundamental Questions. Journal of Management, 34(3), 325-374.

Bandura, Albert (1977). Self-Efficacy: Toward a Unifying Theory of Behavioral Change. Psychological Review 84(2), 191-215.

Battal, Fetullah; Soyalın, Mesut (2020). Algılanan Örgütsel Desteğin Örgütsel Özdeşleşmeye Etkisi: Psikolojik Güvenliğin Aracı Rolü. Journal of Graduate School of Social Sciences, 24(1), 161-173.

Bernarto, Innocentius, Bachtiar, Diana; Sudibjo, Niko; Suryawan, Ian Nurpatria; Purwanto, Agus; Asbari, Masduki (2020). Effect of Transformational Leadership, Perceived Organizational Support, Job Satisfaction toward Life Satisfaction: Evidences from Indonesian Teachers. International Journal of Advanced Science and Technology, 29(3), 5495-5503.

Bolat, Tamer; Seymen, Oya A.; Bolat, Oya İ.; Erdem, Barış (2008). Yönetim ve Organizasyon, Ankara: Detay Yayıncılık.

Carless, Sally A. (2004). Does Psychological Empowerment Mediate the Relationship between Psychological Climate and Job Satisfaction?. Journal of Business and Psychology, 18(4), 405-425.

Chen, S. Y., Wu, W. C., Chang, C. S., Lin, C. T., Kung, J. Y., Weng, H. C., Lee, S. I. (2015). Organizational Justice, Trust, and Identification and Their Effects on Organizational Commitment in Hospital Nursing Staff. BMC Health Services Research, 15(1), 363.

Cheney, George; Tompkins, Phillip K. (1987). Coming to Terms with Organizational Identification and Commitment. Central States Speech Journal, 38(1), 1-15.

Çelik, Vasfiye (2013). Avrupa Birliği’ne Uyum Çerçevesinde Performans Yönetiminin Türk Kamu Yönetiminde Uygulanabilirliği. Yayımlanmamış Doktora Tezi, Gazi Üniversitesi Sosyal Bilimler Enstitüsü, Ankara. 
Conger, Jay A.; Kanungo, Rabindra N. (1988). The Empowerment Process: Integrating Theory and Practice. Academy of Management Review, 13(3), 471-482.

Çuhadar, M. Turan (2005). Türk Kamu Yönetiminde Personel Güçlendirme: Sorunlar ve Çözüm Önerileri. Erciyes Üniversitesi İktisadi ve İdari Bilimler Fakültesi Dergisi, 25(1), 1-21.

Dağlı, Abidin; Baysal, Nigah (2016). Yaşam Doyumu Ölçeğinin Türkçe'ye Uyarlanması: Geçerlik ve Güvenirlik Çalışması. Electronic Journal of Social Sciences, 15(59), 1250-1262.

De Almeida, Helena; Orgambídez, Alejandro (2019). Workplace Empowerment and Job Satisfaction in Portuguese Nurses: An Explicative Model. The Health Care Manager, 38(3), 220-227.

De Cicco, Julie; Laschinger, Heather; Kerr, Michael (2006). Perceptions of Empowerment and Respect: Effect on Nurses' Organizational Commitment in Nursing Homes. Journal of Gerontological Nursing, 32(5), 49-56.

Demircioğlu, Mehmet Akif (2018). The Effects of Empowerment Practices on Perceived Barriers to Innovation: Evidence from Public Organizations, International Journal of Public Administration, 41(15), 1302-1313.

Diener, Ed (1984). Subjective Well-Being. Psychological Bulletin, 95(3), 542-575.

Doğan, Selen; Şahin, Faruk (2015). Kendi Kendine Liderlik Stratejilerinin Yaşam Doyumu Üzerine Etkileri. (Ed. Selen Doğan) Yaşam Doyumu. Ankara: Nobel Akademik Yayıncılık.

Erbay, Elif Ö.; Turgut, Tülay (2015). Yapısal Güçlendirme ve Örgütle Özdeşleşme Arasındaki İlişkide Psikolojik Güçlenmenin Ara Değişken Etkisi. Marmara University Journal of Economic and Administrative Sciences, 37(2), 261-284.

Erkul, Hüseyin; Kanten, Pelin; Gümüştekin, Gülten (2018). The Effects of Structural Empowerment on Corporate Reputation and Organizational Identification. Acta Academica Karviniensia, 3(1), 27-41.

Fernandez, Sergio; Tima Moldogaziev (2011). Empowering Public Sector Employees to Improve Performance: Does It Work? The American Review of Public Administration, 41(1), 23-47.

Fernandez, Sergio; Moldogaziev, Tima (2013a). Using Employee Empowerment to Encourage Innovative Behavior in the Public Sector. Journal of Public Administration Research and Theory, 23(1), 155-187.

Fernandez, Sergio; Moldogaziev, Tima (2013b). Employee Empowerment, Employee Attitudes, and Performance: Testing a Causal Model. Public Administration Review, 73(3), 490-506. 
Fernandez, Sergio; Moldogaziev, Tima (2015). Employee Empowerment and Job Satisfaction in the US Federal Bureaucracy: A Self-Determination Theory Perspective. The American Review of Public Administration, 45(4), 375-401.

Foy, Tommy; Dwyer, Rocky J.; Nafarrete, Roy; Hammoud, Mohamad S.S.; Rockett, Pat (2019). Managing Job Performance, Social Support and Work-Life Conflict to Reduce Workplace Stress, International Journal of Productivity and Performance Management, 68(6), 1018-1041.

Greco, Paula; Spence Laschinger, Heather K.; Wong, Carol (2006). Leader Empowering Behaviours, Staff Nurse Empowerment and Work Engagement/Burnout. Nursing Leadership, 19(4), 41-56.

Hackman, Richard; Oldham, Greg R. (1976). Development of the Job Diagnostic Survey. Journal of Applied Psychology, 60(2), 159-170.

İşcan, Ömer Faruk (2006). Dönüştürücü/Etkileşimci Liderlik Alg1sı ve Örgütsel Özdeşleşme İlişkisinde Bireysel Farklılıkların Rolü. Akdeniz İ.İ.B.F. Dergisi, 11(6), 160-177.

Jaffery, Hina; Farooq, Hassan (2015). The Impact of Structural Empowerment on Organizational Citizenship Behavior-Organization and Job Performance: A Mediating Role of Burnout. Journal of Management Sciences, 2(2), 273-288.

Johnson, William L.; Johnson, Annabel M.; Heimberg, Felix (1999). A Primary-and Second-Order Component Analysis of the Organizational Identification Questionnaire. Educational and Psychological Measurement, 59(1), 159-170.

Kanten, Pelin (2012). İşgörenlerde İşe Adanmanın ve Proaktif Davranışların Oluşumunda Örgütsel Güven ile Örgütsel Özdeşleşmenin Rolü. Yayımlanmamış Doktora Tezi, SDÜ Sosyal Bilimler Enstitüsü, Isparta.

Kanter, Rosabeth M. (1977). Men and Women of the Corporation. New York: Basic Books.

Kerse, Gökhan; Karabey, Canan Nur (2017). Alg1lanan Örgütsel Desteğin Örgütsel Özdeşleşmeye Etkisi: Örgütsel Sinizmin Aracı Rolü. MANAS Sosyal Araştırmalar Dergisi 6(4), 375-398.

Kimura, Takuma (2011). Empowerment, PO Fit, and Work Engagement: A Mediated Moderation Model. European Journal of Economics, Finance and Administrative Sciences, 38(2), 44-58.

Kuzulu, Ece; Kurtuldu, Selver; Vural Özkan, Gülşah (2013). İş Yaşam Dengesi ile Yaşam Doyumu İlişkisi Üzerine Bir Araştırma. Sakarya İktisat Dergisi2(1), 88-127

Lautizi, Marina;Laschinger, Heather K.. S.; Ravazzolo, Sandra (2009). Workplace Empowerment, Job Satisfaction and Job Stress among Italian Mental Health Nurses: An Exploratory Study. Journal of Nursing Management, 17(4), 446-452. 
Lyubomirsky, Sonja; Sheldon, Kennon M.; Schkade, David (2005). Pursuing Happiness: The Architecture of Sustainable Change. Review of General Psychology, 9(2), 111-131.

Laschinger, Heather K. S. (1996). A Theoretical Approach to Studying Work Empowerment in Nursing: A Review of Studies Testing Kanter's Theory of Structural Power in Organizations. Nursing Administration Quarterly, 20(2), 2541.

Laschinger, Heather K. S.; Finegan, Joan; Shamian, Judith; Wilk, Piotr (2001). Impact of Structural and Psychological Empowerment on Job Strain in Nursing Work Settings: Expanding Kanter's Model. Journal of Nursing Administration, 31(5), 260-272.

Laschinger, Heather K. S.; Finegan, Joan; Shamian, Judith; Wilk, Piotr (2003). Workplace Empowerment as a Predictor of Nurse Burnout in Restructured Healthcare Settings. Healthcare Quarterly, 6(4), 2-11.

Laschinger, Heather K. S.; Finegan, Julia; Shamian, J.; Wilk, Piotr. (2004). A Longitudinal Analysis of the Impact of Workplace Empowerment on Work Satisfaction. Journal of Organizational Behavior, 25(4), 527-545.

Laschinger, Heather K.; Finegan, Julia (2005). Empowering Nurses for Work Engagement and Health in Hospital Settings. The Journal of Nursing Administration, 35(1), 439-449.

Laschinger, Heather K. S.; Finegan, Julia; Wilk, Piotr. (2009). Context Matters: The Impact of Unit Leadership and Empowerment on Nurses' Organizational Commitment. Journal ofNursing Administration, 39(5), 228-235.

Mael, Fred; Ashforth, Blake E. (1992). Alumni and their Alma Mater: A Partial Test of the Reformulated Model of Organizational Identification. Journal of Organizational Behaviour, 13(1), 103-123.

Meng, Bo; Han, Heesup (2014). The Effects of Empowerment on Employee Psychological Outcomes in Upscale Hotels. Journal of Hospitality Marketing \& Management, 23(2), 218-237.

Meng, Lina; Liu, Yanhui; Liu, Hongwei; Hu, Yu; Yang, Jipeng; Liu, Jingying (2015). Relationships among Structural Empowerment, Psychological Empowerment, Intent to Stay and Burnout in Nursing Field in Mainland China-Based on a CrossSectional Questionnaire Research. International Journal of Nursing Practice, 21(3), 303-312.

Meng, Lina; Jin, Yi; Guo, Jiajia (2016). Mediating and/or Moderating Roles of Psychological Empowerment. Applied Nursing Research,30(1), 104-110.

O’Brien, Janice L. (2011). Relationships among Structural Empowerment, Psychological Empowerment, and Burnout in Registered Staff Nurses Working in Outpatient Dialysis Centers. Nephrology Nursing Journal, 38(6), 475-481. 
Özarallı, Nurdan (2017). İşe Tutkunluğun, Yapısal Güçlendirme, Örgütsel Özdeşleşme ve Hedeflerin İçselleştirilmesi Yoluyla Geliştirilmesi. International Journal of Social Sciences and Education Research, 3(4), 1258-1273.

Özer, Mehmet Akif (2019). Yeni Kamu Yönetimi, Kamu Yönetiminde Çağdaş Yaklaşımlar. Eskişehir: Anadolu Üniversitesi Yayınları.

Özgözgü, Serdal (2016). Kurumsal İmaj, Örgüt Kültürü ve Örgütsel Özdeşleşme İlişkisi. Kastamonu Education Journal, 25(2).581-596.

Öztürk, Hülya (2010). Yoğun Bakımlarda Çalışan Hemşirelerin Güçlendirme Algısı ve Ortamı Güçlendirme Açısından Değerlendirmeleri. Yayımlanmamış Yüksek Lisans Tezi, Hacettepe Üniversitesi Sağlık Bilimleri Enstitüsü, Ankara.

Polat, Mustafa; Meydan, Cem H. (2010). Örgütsel Özdeşleşmenin Sinizm ve İşten Ayrılma Niyeti ile İlişkisi Üzerine Bir Araştırma. Savunma Bilimleri Dergisi, 9(1), 145172.

Proctor, Carmel L.; Linley, P. Alex; Maltby, John (2009). Youth Life Satisfaction: A Review of the Literature. Journal of Happiness Studies, 10(5), 583-630.

Quinn, Robert E.; Spreitzer, Gretchen M. (1997). The Road to Empowerment: Seven Questions Every Leader Should Consider. Organizational Dynamics, 26(2), 37-49.

Seçtim, Hafize (2019). Sağlıkta Dönüşüm Programı Üzerine Bir Değerlendirme. Management and Political Sciences Review,1(1), 117-133.

Seligman, Martin E. P. (2007). Gerçek Mutluluk Kalıcı Doyum Potansiyelinizi Geliştirmek İçin Yeni Olumlu Psikolojinin Kullanılması, Ankara: HYB.

Spreitzer, Gretchen M. (1995). Psychological Empowerment in the Workplace: Dimensions, Measurement, and Validation, Academy of Management Journal, 38(5), 1442-1465.

Spreitzer, Gretchen M. (1996). Social Structural Characteristics of Psychological Empowerment. Academy of Management Journal, 39(2), 483-504.

Sürgevil, Olca; Tolay, Ebru; Topoyan, Mert (2013). Yapısal Güçlendirme ve Psikolojik Güçlendirme Ölçeklerinin Geçerlilik ve Güvenilirlik Analizleri. Journal of Yasar University, 8(31), 5371-5391.

Şimşek, Eylem; Aktaş, Hakkı (2014). Örgütsel Sessizlik ile Kişilik ve Yaşam Doyumu Etkileşimi: Kamu Sektöründe Bir Araştırma. Anadolu University Journal of Social Sciences, 14(2), 121-136.

Thomas, Kenneth; Velthouse, Betty (1990). Cognitive Elements of Empowerment: An Interpretive Model of Intrinsic Task Motivation. Academy Management Review, 15(4), 666-681. 
Tolay, Ebru; Sürgevil, Olca; Topoyan, Mert (2012). Akademik Çalışma Ortamında Yapısal ve Psikolojik Güçlendirmenin Duygusal Bağlılık ve İş Doyumu Üzerindeki Etkileri. Ege Akademik Bakış, 12(4), 449-465.

Tompkins, Phillip K.; Cheney, George. (1985). Communication and Unobtrusive Control in Contemporary Organizations. Organizational Communication: Traditional Themes and New Directions, 13(1), 179-210.

Tüzün, İpek K.; Çağlar, İrfan (2008). Örgütsel Özdeşleşme Kavramı ve İletişim Etkinliği İlişkisi. Journal of Yaşar University, 3(9), 1011-1027.

Uppal, Muhammad Amaad; Ali, Samnan; Gulliver, Stephen R. (2018). Factors Determining E-learning Service Quality. British Journal of Educational Technology, 49(3), 412-426.

Wallach, Vicki A.; Mueller, Charles W. (2006). Job Characteristics and Organizational Predictors of Psychological Empowerment among Paraprofessionals within Human Service Organizations: An Exploratory Study. Administration in Social Work, 30(1), 95-115.

Yanar, Başak (2005). The Moderating Effects of Idiocentrism and Allocentrism, Management Power Styles and Valence of Self Goals on the Relationship between Organizational Identification and Conflict Handling Styles. Yayımlanmamış Yüksek Lisans Tezi, MÜ Sosyal Bilimler Enstitüsü, İstanbul.

Zencirkıran, Memet; Keser, Aşkın (2018). Örgütsel Davranış. Bursa: Dora Basım Yayın. 